\title{
Metaconglomerados e rochas associadas do Grupo São Roque a norte da cidade de São Paulo, Brasil
}

\author{
Renato Henrique-Pinto ${ }^{1}$ \& Valdecir de Assis Janasi ${ }^{1}$
}

\begin{abstract}
Resumo O Grupo São Roque caracteriza-se por rochas depositadas em ambiente marinho com atividade vulcânica submarina, as ocorrências da Formação Morro Doce são dominadas por metarcóseos e metarenitos feldspáticos com expressivas lentes de metaconglomerados, que formam uma seqüência considerada como unidade basal do Grupo São Roque. Rochas metavulcânicas ácidas e básicas intercaladas nesta seqüência constituem importante marcador tectônico e geocronológico, e foram usadas para determinar sua idade de deposição (1.75-1.79 Ga). O estudo petrográfico dos clastos graníticos dos metaconglomerados permitiu a identificação de quatro variedades petrográficas: biotita monzogranito porfirítico, monzogranito inequigranular, monzogranito equigranular e leucogranito inequigranular. O caráter comagmático entre os clastos é confirmado pelos dados geoquímicos e geocronológicos. Rochas metavulcânicas ácidas que ocorrem intercaladas a metarcóseos e metaconglomerados, na região do Morro do Polvilho, caracterizam-se por meta-traquidacitos e meta-riolitos porfiríticos. Com características geoquímicas típicas de magmatismo intraplaca, em especial baixo mg\# ( 20), altos teores de $\mathrm{Zr}$ (560-730 ppm), Y e Nb, além de baixo Sr (70-120 ppm), as rochas metavulcânicas ácidas do Grupo São Roque apresentam similaridades com as metavulcânicas ácidas da base do Supergrupo Espinhaço. Por outro lado, o corpo anfibolítico do Jaraguá, de idade ainda desconhecida, parece ser intrusivo na Formação Morro Doce tem características geoquímicas mais próximas de magmatismo de fundo oceânico, com baixas concentrações de elementos incompatíveis como $\mathrm{Rb}, \mathrm{Nb}$ e $\mathrm{Th}$, o que as aproximam das rochas metabásicas supracrustais da região de Pirapora do Bom Jesus.
\end{abstract}

Palavras-chave: Grupo São Roque, metaconglomerados, ambientes tectônicos.

\begin{abstract}
Metacoglomerates and associated rocks of the São Roque Group, northern São Paulo city, Brazil. The São Roque Group is composed of rocks deposited in marine environment with coeval volcanic activity, the Morro Doce Formation is dominated by meta-arkose and feldspatic meta-sandstone with expressive metaconglomeratic lenses, which form a sequence regarded as the basal unit of São Roque Group. Metavolcanic acidic and basic rocks interspersed in this sequence are an important tectonic and geochronologic marker (1.75-1.79 $\mathrm{Ga}$ ). The petrographic study of the granite pebbles from the Morro Doce Formation metaconglomerates allowed the identification of four petrographic varieties: porphyritic biotite monzogranite, inequigranular monzogranite, equigranular monzogranite and inequigranular leucogranite. The comagmatic character of these pebbles is confirmed by petrographic and geochemical data. Acid metavolcanic rocks interlayered with meta-arkose and metaconglomerates in the Morro do Polvilho region correspond to trachydacite and porphyritic meta-rhyolite. The meta-arkose shows geochemical affinities with metaconglomerate granitic pebbles, and differs from the acid metavolcanic rocks both in their geochemical signature and in its sedimentary fabrics. Their geochemical characteristics are typical of within-plate magmatism, especially the low $\mathrm{mg} \#(\sim 20)$, high $\mathrm{Zr}$ (560-730 ppm), Y, Nb, and low $\mathrm{Sr}$ (70-120 ppm), and is similar to the acid metavolcanics from the on Espinhaço Supergroup. The Jaraguá amphibolite body, still of unknown age, seems to be intrusive into the Morro Doce Formation, and has geochemical characteristics akin to ocean-floor magmatism, with low concentrations of incompatible elements such as Rb, $\mathrm{Nb}$ and $\mathrm{Th}$, and are similar to supracrustal metabasics from the Pirapora do Bom Jesus region.
\end{abstract}

Keywords: São Roque Group, metacoglomerates, tectonics environment.

INTRODUÇÃO A cadeia de montanhas que compõe as faixas dobradas da porção leste do Brasil, chamada por Eschwege (1824) de "serra do Espinhaço", abriga antigas bacias sedimentares cujas idades e correlações ainda são temas controversos. Parte desta cadeia de montanhas, localizada nos Estados de Minas Gerais e São Paulo, recebe o nome Serra da Mantiqueira, e especificamente a norte de São Paulo, Serra da Cantareira (Derby, 1895).
A "serie de xistos metamorphycos" (Oliveira, 1887) que compõe parte do substrato rochoso que sustenta as regiões elevadas no Estado de São Paulo foi chamada por Gonzaga de Campos (1888) de "camadas de São Roque", e posteriormente de "Série de São Roque" (Oliveira 1925). Esta seqüência que se expõe principalmente a norte da cidade de São Paulo foi elevada à categoria de Grupo São Roque em 1963 (Paoliello, 1964). 
O Grupo São Roque caracteriza-se por rochas depositadas em ambiente marinho (Moraes Rego, 1933), com atividade vulcânica submarina (Carneiro et al. 1984). As ocorrências da Formação Morro Doce (Juliani et al. 1999) são dominadas por metarcóseos e metarenitos feldspáticos com expressivas lentes metaconglomeráticas, que formam uma seqüência considerada como unidade basal do Grupo São Roque. Os metaconglomerados que afloram a norte da cidade de São Paulo têm chamado a atenção dos geólogos desde os trabalhos de Coutinho (1955), e o amplo predomínio de clastos graníticos tem excelente potencial para identificação de suas fontes e idades.

Datação U-Pb em monazita de rocha metabásica apresentada por Hackspacher et al. (2000) (628 \pm $9 \mathrm{Ma}$ ) foi interpretada como indicativa de que o Grupo São Roque se depositou no Ediacarano, tratando-se de unidade mais jovem que o Grupo Serra do Itaberaba, do Mesoproterozóico (Juliani et al. 2000). Datações K-Ar em biotita do arcabouço do metaconglomerado sugerem, no entanto, idades de metamorfismo da ordem de $800 \mathrm{Ma}$ (Tassinari et al. 1985).

A deposição do Grupo São Roque tem sido determinada com maior segurança através de datações $\mathrm{U}-\mathrm{Pb}$ de rochas metavulcânicas ácidas e básicas que ocorrem intercaladas na Formação Morro Doce (Carneiro et al. 1984), e indicam idades na passagem Estateriano-Caliminiano $(1790+14 \mathrm{Ma}$, van Schmus et al. 1986; 1750 $\pm 40 \mathrm{Ma}$; Oliveira et al. 2008). Esta idade sugere que a sedimentação do Grupo São Roque teve início a partir da "Tafrogênese Estateriana" (Brito Neves et al. 1995), o que abre a possibilidade de cronocorrelação com a base do Supergrupo Espinhaço (Schobbenhaus et al., 1994; Brito Neves et al., 1979) e a base do Supergrupo Açungui (Basei et al. 2003; Weber et al. 2004).

A idade obtida por Van Schmus et al. (1986) foi questionada por Juliani et al. (1997) com base na petrografia, uma vez que os meta-riodacitos por eles datados foram reinterpretados como metarcóseos. Portanto, por essa ótica, os zircões datados seriam detríticos, o que representaria a idade de uma das fontes, e não da deposição do pacote sedimentar intercalado com essas rochas.

Em uma fase inicial, a presente pesquisa explorou a possibilidade de proveniência dos metaconglomerados do Grupo São Roque a partir de um arco magmático continental neoproterozóico, sugerido pela datação e interpretação paleogeográfica (bacia de "back-arc") de Hackspacher et al. (2000). Foi feita uma comparação geoquímica detalhada entre os clastos dos metaconglomerados e os granitos neoproterozóicos, a partir das variedades petrograficamente similares às identificadas nos clastos. Embora tenham sido reveladas similaridades com alguns dos granitos neoproterozóicos do batólito Agudos Grandes (Henrique-Pinto \& Janasi 2007), discrepâncias para importantes elementos traços como $\mathrm{Rb}, \mathrm{Nb}$ e $\mathrm{Ga}$ mostraram que os clastos não têm equivalência com nenhum dos granitos neoproterozóicos regionais conhecidos.

Os clastos graníticos do metaconglomerado foram estudados em detalhe por Henrique-Pinto (2008) e datados em $2.2 \mathrm{Ga}$ (U-Pb por LA-MC-ICPMS), que é, portanto a idade da área-fonte predominante da Fm. Morro Doce, consistente com a idade de deposição dos metaconglomerados de 1.75-1.79 Ga, indicada pelas datações U-Pb em rochas metavulcânicas intercaladas.

SITUAÇÃO TECTÔNICA Moraes Rego (1931) chamou de Pré-Brasilides as estruturas que se anexaram a escudos arqueanos para dar origem à "grande molhe continental chamada Brasilia". No Brasil, a fragmentação dessa grande massa continental resultou na geração de bacias oceânicas, com sedimentação provavelmente iniciada ao final do Paleoproterozóico (Brito Neves et al. 1995). Registros da geração de um "supercontinente" durante o período Orosiriano, com fragmentação iniciada no Estateriano, são encontrados em outras partes do mundo (Condie 2002; Rogers \& Santosh 2002).

O Grupo São Roque caracteriza-se por rochas depositadas em ambiente marinho (Moraes Rego 1933) com atividade vulcânica submarina (Carneiro et al. 1984). Está localizado na Província Estrutural Mantiqueira (Almeida et al. 1981), e seria parte, segundo diferentes autores, da Faixa de Dobramentos Ribeira (Hasui et al. 1975a), Faixa Apiaí (Campos Neto \& Figueiredo 1995) ou Domínio Apiaí (Campanha \& Sadowski 1999). No modelo tectônico de Campos Neto 2000, ele faz parte do Domínio Apiaí-São Roque, que é limitado a sul pelo Domínio Embu (Complexos Pilar e Embu) e a norte pelo Domínio Socorro Guaxupé (Fig. 1).

Uma seqüência vulcano-sedimentar presente na região da Serra do Itaberaba foi caracterizada como a base do Grupo São Roque (Coutinho et al. 1982), sendo composta por vulcânicas e sub-vulcânicas básicas e seus tufos, bem como camadas argilosas, margas e intercalações de sedimentos químicos silicosos. Acima desta seqüência foi descrito um pacote com menor metamorfismo, representado na base por "metarcóseos rítmicos" sucedido por filitos com intercalações quartzíticas (Campos Neto et al. 1983).

A seqüência basal foi posteriormente distinguida como Grupo Serra do Itaberaba por Juliani et al. (1986), que a subvidiram em três formações. A Formação Morro da Pedra Preta (basal) composta por rochas metavulcanoclásticas, calciossilicáticas, e formações ferríferas, sobreposta pela Formação Nhanguçu, composta por sedimentos clasto-químicos; a Formação Pirucaia formada por rochas essencialmente quartzíticas, corresponderia às fácies marginais da bacia, e seria cronocorrelata às outras duas.

Esta seqüência foi separada do Grupo São Roque principalmente por tratar-se de rochas que registram "durante o desenvolvimento da foliação $\mathrm{S}_{1}$ ", grau metamórfico predominantemente da fácies anfibolito médio, em contraposição ao Grupo São Roque (fácies xistos verdes). $\mathrm{O}$ contato erosivo entre os dois grupos seria atestado pela presença de clastos de fragmentos vulcânicos relacionados ao Grupo Serra do Itaberaba nos metaconglomerados da base do Grupo São Roque (Juliani 1993; Martin 2000). Juliani et al. (2000) apresentaram idade U-Pb em zircão de $1395 \pm 10$ Ma para 


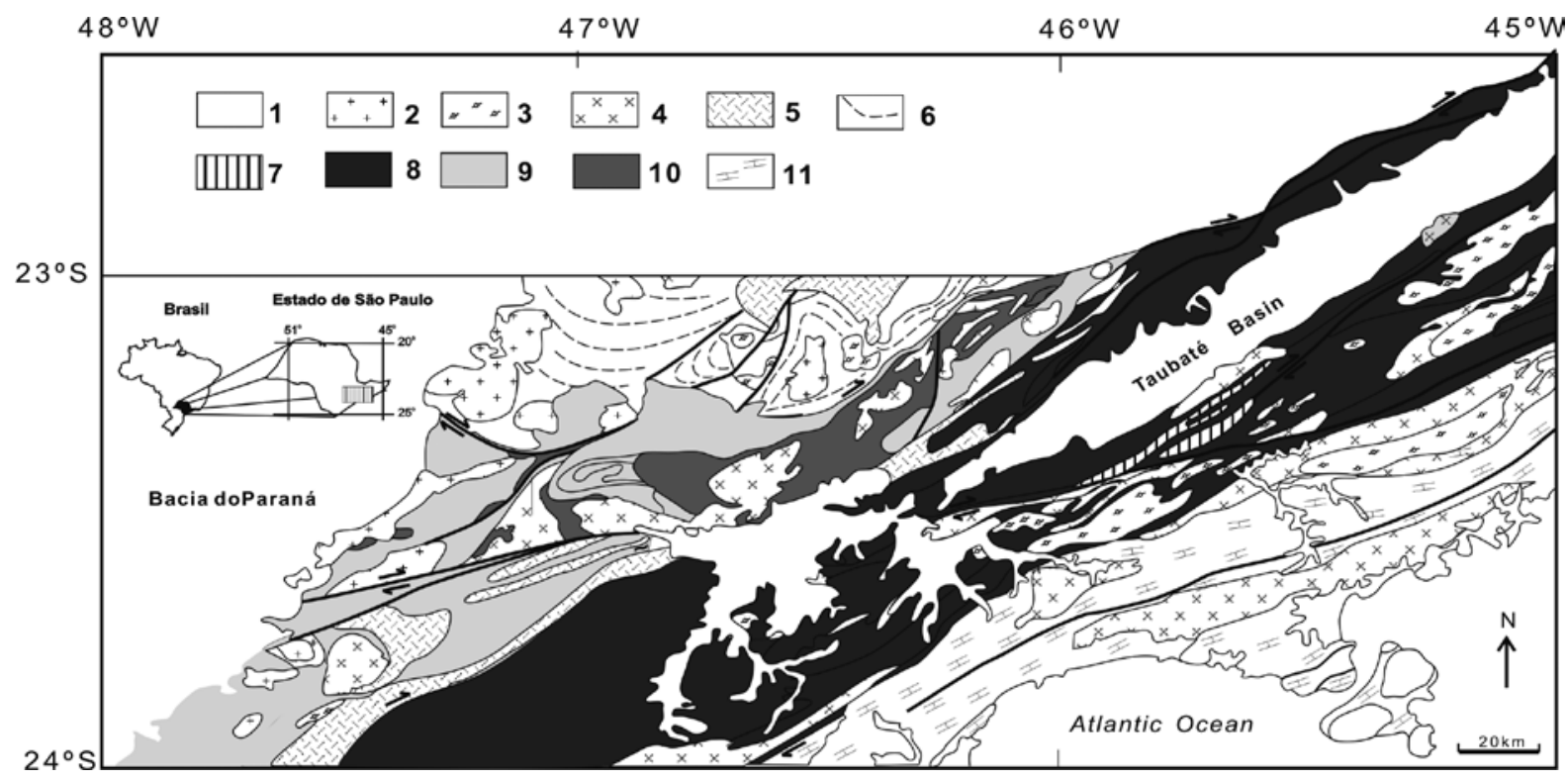

Figura 1 - Mapa Geotectônico modificado de Campos Neto (2000). 1- Coberturas fanerozóicas e rochas intrusivas; 2- Granitos tardi e pós-tectônicos; 3- (Granada)-(muscovita)-miotita granitos; 4Biotita granitos porfiriticos; 5- Hornblenda-biotita granitos porfiriticos; 6- Domínio Socorro- Guaxupé (predomínio de granada migmatitos); 7- Gnaisses paleoproterozóicos; 8- Domínio Embu (Complexos Pilar e Embu); 9- Grupo São Roque; 10- Grupo Serra do Itaberaba; 11- Complexo Costeiro.

meta-andesito da Formação Morro da Pedra Preta, posicionando a deposição do Grupo Serra do Itaberaba no Mesoproterozóico.

A zona de falhamento transcorrente de Jundiuvira foi caracterizada como uma descontinuidade limítrofe entre blocos, separando o "Bloco São Roque" do "Bloco Jundiaí", situado a norte (Hasui et al. 1969). As rochas da região da Serra do Japi foram incluídas por Wernick (1976) no Grupo Amparo, e divididas em membros pelíticos ("Formações Ermida") e psamo-pelíticos ("Formação Japi"), sem continuidade com as rochas do Grupo São Roque, o que também foi observado por Hasui et al. (1978). No entanto, Moraes (1944) e Campos Neto (2000), admitem que os metassedimentos da Serra do Japi constituam continuidade do Grupo São Roque a norte deste limite (Fig. 1).

O magmatismo granítico é intenso no Domínio Apiaí-São Roque, caracterizado por Campos Neto (2000) como um arco magmático desenvolvido na margem do cráton Paranapanema. É dominado por granitos cálcio-alcalinos potássicos neoproterozóicos, que constituem a massa principal de três extensos batólitos alongados na direção NE-SW (Cunhaporanga, Três Córregos e Agudos Grandes). Inúmeros plútons isolados, incluindo as principais intrusões no Domínio São Roque, devem constituir satélites dessas grandes massas graníticas, tendo em vista as semelhanças composicionais e de idade (Janasi \& Ulbrich 1991) (Fig. 1).

GEOLOGIA LOCAL A área de estudo concentrase nas ocorrências da Formação Morro Doce (Juliani 1999), considerada unidade basal do Grupo São Roque (Coutinho 1955); parte das rochas em estudo foi tam- bém posicionada como seqüência inferior (Cordani et al. 1961; Dantas 1990), e chamada de Formação Boturuna (Hasui 1973). Outras designações como "pacote superior" (Campos Neto et al. 1983), unidade "metapsamítica impura" (Carneiro 1983) ou "associação siliciclástica basal" (Fernandes da Silva 2004), também foram usadas para definir ocorrências similares, embora definidas em diferentes localidades.

Para a base do Grupo São Roque, Martin (2000) propõe correlação lateral entre as Formações Morro Doce (Juliani et al. 1999) e Pirapora (Bergmann 1988). Em contato transicional com metarcóseos e metaconglomerados da Formação Morro Doce, estariam representados os sedimentos da Formação Boturuna (Hasui 1973). A unidade de topo, composta predominantemente por sedimentos rítmicos, foi comparada por Martin (2000) à Formação Piragibu (Hasui 1973), e ao membro arenoso da Formação Estrada dos Romeiros (Bergmann 1988).

A maior área de ocorrência da Formação Morro Doce encontra-se a noroeste da cidade de São Paulo, na porção sudeste da Folha Santana do Parnaíba (IPT 1983). Esta Formação caracteriza-se por predomínio de metarcóseos que se interdigitam com espessas lentes de metaconglomerados polimíticos de seixos e calhaus estirados, sustentados por um arcabouço bem recristalizado. Nas regiões topograficamente mais elevadas, como o Pico do Jaraguá, ocorrem metarenitos e metarenitos feldspáticos. Pequenos corpos de rochas metavulcânicas encontram-se intercalados no pacote, como rochas metavulcânicas básicas (ex: pequenos corpos dentro da unidade de metarcóseos) e "metariodacitos" (da região do Morro do Polvilho).

O corpo anfibolítico do Jaraguá, com dimen- 
sões de aproximadamente 1,5 x 2,5 km (Gomes 1962), ocorre a oeste do Granito Cantareira, em aparente discordância em relação aos xistos e quartzitos. Pequenas manchas de metacalcários impuros circundam localmente a ocorrência.

Ocorrências de estaurolita xistos, que devem estar associadas ao Grupo Serra do Itaberaba encontram-se embutidas no pacote de metarcóseos, mas as relações de contato não puderam ser definidas em decorrência do intemperismo. No centro-norte da área de estudo (Fig. 2) aparecem expressivas ocorrências de rochas cálcio-silicatadas (Cordani 1963).

Entre os plútons graníticos neoproterozóicos que aparecem na área do mapa (Fig. 2) destacam-se os batólitos Itaqui e Cantareira que, segundo IPT (1983), são separados entre si por zonas miloníticas, e um pequeno plúton presente na região da Fazenda Ithayê, intrudindo a unidade de metarcóseos. Todas estas ocorrências apresentam características petrográficas similares (biotita granitos porfiríticos, em parte com hornblenda). Diferem destas ocorrências o Granito Tico-Tico, constituído por leucogranitos a duas micas, que é intrusivo no Grupo Serra do Itaberaba, e veios pegmatíticos que ocorrem ocasionalmente invadindo o pacote de metarcóseos.

Metaconglomerados Uma expressiva exposição de metaconglomerados da Formação Morro Doce encontra-se nas pistas sul e norte do Rodoanel Viário Metropolitano de São Paulo (km 9,5), na região do Morro Doce (Ponto MD-01) (Henrique-Pinto 2008). Outras ocorrências estudadas encontram-se na região da Fazenda Itahyê (Ponto MD-25) e Morro do Polvi-
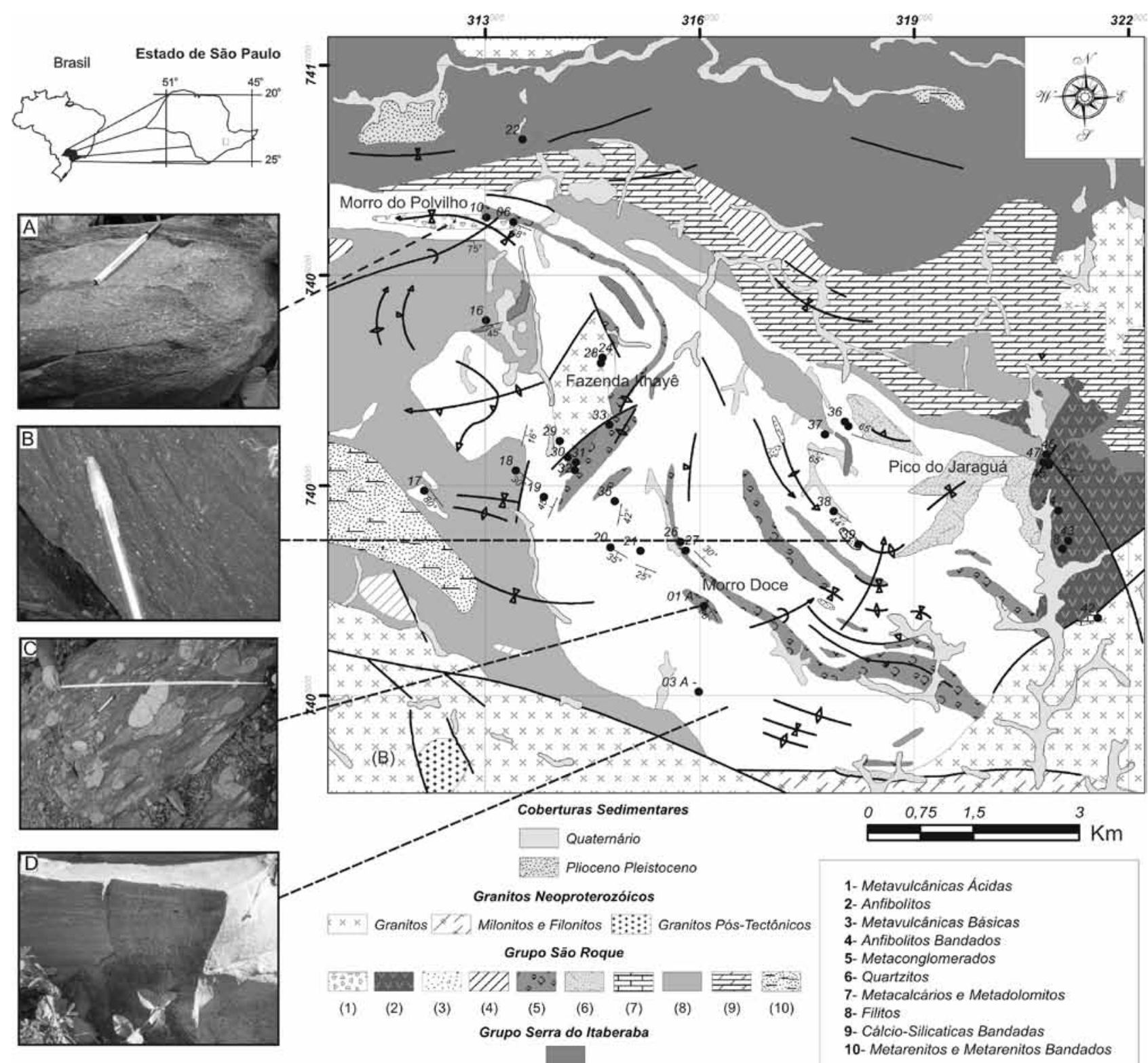

1- Metavulcánicas Ácidas

2- Anfibolitos

3- Metavulcánicas Básicas

4- Anfibolitos Bandados

5- Metaconglomerados

6- Quartzitos

7- Metacalcários e Metadolomitos

8. Filitos

9- Cálcio-Silicaticas Bandadas

10-Metarenitos e Metarenitos Bandados

Figura 2 - Mapa Geológico da Folha Santana de Parnaíba (SF-23-Y-C-III-3): Noroeste da cidade de São Paulo - modificado de IPT (1981): A-Metavulcânicas Ácidas; B-Metavulcânicas Básicas; C-Metaconglomerados; D-Metarcóseos. 
lho (Ponto MD-10) (Fig. 2).

Em todas essas exposições, os metaconglomerados caracterizam-se como polimíticos, com calhaus e seixos de dimensões variadas, a maioria com 10 a 20 $\mathrm{cm}$; os maiores podem alcançar até $50 \mathrm{~cm}$ para o eixo de elongação maior. Muitos dos clastos se tocam, porém entre eles sempre aparecem vestígios de arcabouço. São amoldados pela deformação, de modo que os contatos entre os seixos podem ser sinuosos. As características estruturais observadas assemelham-se às descritas por Coutinho $(1955,1968)$ em outras ocorrências desta unidade, nas quais a deformação não apaga por completo $o$ acentuado arredondamento original dos clastos graníticos. Muitos, entretanto, também exibem forte deformação, manifestada por feições como interpenetração, elongamento assimétrico e fragmentação de material dentro do arcabouço (Fig. 2C). A exposição do Morro Doce mostra uma aparente orientação da petrotrama pretérita à deformação, indicativa de um possível imbricamento provocado por transporte em ambiente fluvial, porém não se descarta a possibilidade de se tratar de depósitos gerados por fluxo de massa (Turra et al. 2007).

Os metaconglomerados da região do Morro Doce registram efeitos hidrotermais de carbonatização e sulfetação ao longo de veios e microvenulações. Os veios de quartzo e calcita mais expressivos aparecem posicionados ortogonalmente à foliação principal, porém as ramificações são disseminadas por toda a exposição. A introdução de pirita secundária pode ser responsável pela redução nos valores de susceptibilidade magnética $(\mathbf{S M})$ nos clastos graníticos $(\mathrm{K}=0,07-0,47 \mathrm{x}$ $10^{-3} \mathrm{SI}$ ), uma vez que os metaconglomerados da região da Fazenda Itahyê e do Morro do Polvilho, apesar da intensa deformação e da presença de pirita, mostramse menos afetados pelo hidrotermalismo, e seus clastos graníticos registram valores de SM significativamente mais altos $\left(\mathrm{K}=2,1-12,2 \times 10^{-3} \mathrm{SI}\right)$.

PETROGRAFIA DOS CLASTOS Embora os metaconglomerados da Formação Morro Doce sejam polimíticos, existe um amplo predomínio de clastos graníticos, que formam cerca de 80 a $90 \%$ do volume total, e apresentam características petrográficas similares em todas as exposições estudadas. Os demais litotipos encontrados correspondem a quartzitos e rochas metabásicas (Figs. 3E e F, respectivamente), que não foram estudados em maior detalhe neste trabalho.

Por apresentarem maior resistência à deformação, os clastos graníticos, principalmente aqueles de maior dimensão (acima de $20 \mathrm{~cm}$ ), ainda preservam estruturas reliquiares. Predominam amplamente biotita monzogranitos leucocráticos equigranulares e inequigranulares, de granulação média a grossa com baixo índice de cor $(\mathbf{I C}=3-5)$; embora muito restritas, foram também encontradas variedades porfiríticas com $\mathbf{I C}=6-7$. As diferenças texturais e petrográficas dos clastos graníticos permitiram a caracterização de quatro variedades:

-Biotita Monzogranito Porfiritico $\quad(\mathbf{I C}=6-7)$ (Fig. 3A) apresenta textura porfiroclástica, com megacristais de microclínio rotacionados, com peque- nas inclusões de plagioclásio (andesina-oligoclásio), circundados por uma matriz fina composta por quartzo e feldspatos granoblásticos, muscovita e biotita associada a clorita nas bordas. O quartzo apresenta-se bem recristalizado, com contatos serrilhados, e entre os minerais acessórios mais comuns aparecem zircão, apatita, allanita, epidoto, titanita, minerais opacos e calcita.

-Monzogranito Inequigranular $(\mathbf{I C}=3-5)$ (Fig. 3B) apresenta textura granular hipidiomórfica média a grossa (4-6 mm). O plagioclásio (andesina-oligoclásio) encontra-se intensamente sericitizado, com hábito parcialmente preservado e geminações deformadas. O quartzo é xenomórfico de contatos interlobados a serrilhados. Entre os minerais acessórios mais comuns aparecem titanita, allanita euédrica, apatita e zircão, este último definindo expressivos halos pleocróicos em cristais de biotita. Entre os minerais opacos predomina a pirita; calcita ocorre em microvenulações.

-Monzogranito Equigranular $(\mathbf{I C}=3-5)$ (Fig. 3C) apresenta textura granular hipidiomórfica média (3-4 $\mathrm{mm}$ ). O plagioclásio (oligoclásio-andesina) está fortemente sericitizado, porém com geminações ainda visíveis. O quartzo é xenomórfico de contatos interlobados a serrilhados. É comum a associação entre mineral opaco e biotita com bordas substituídas por clorita. Os minerais acessórios mais comuns são minerais opacos euédricos, titanita e carbonatos subidiomórficos.

-Leucogranito Inequigranular (IC= 2-3) (Fig. 3D) apresenta textura granular hipidiomórfica grossa (5-7 mm); apesar da intensa deformação, alguns aspectos da textura ígnea original ainda podem ser observados. Os cristais de plagioclásio (oligoclásio) muitas vezes estão inclusos em feldspato alcalino pertítico; já o quartzo encontra-se xenomórfico de contatos interlobados a serrilhados. É comum a associação mineral opaco-biotitaclorita-titanita; epidoto e calcita são euédricos e ocorrem em relações texturais que sugerem crescimento tardio.

Metarcóseos Os metarcóseos, rochas de maior expressão da Formação Morro Doce, abrigam as maiores ocorrências de metaconglomerados, com os quais ocorrem intercalados. Quando inalterados, os metarcóseos apresentam brilho "sedoso" e bandamento composicional (Fig. 2D); os valores de susceptibilidade magnética são baixos $\left(\mathrm{K} \leq 0,2 \times 10^{-3} \mathrm{SI}\right)$.

Os metarcóseos e metarenitos arcoseanos apresentam petrotrama sedimentar composta predominantemente por feldspatos detríticos sub-angulosos dispersos em uma matriz fina constituída essencialmente por muscovita, biotita, clorita e pequenas acumulações de quartzo. Entre os minerais acessórios mais comuns aparecem titanita, zircão, minerais opacos e calcita.

Rochas Metavulcânicas A maior manifestação do magmatismo básico da região estudada corresponde ao corpo anfibolítico do Jaraguá (Gomes 1962); estas ocorrências foram designadas anfibolitos metabasíticos por Carneiro (1983). Aparentemente discordante com relação ao pacote metapsmítico, com feições de mapa sugerindo um contato intrusivo de geometria oval (Fig. 2), o 

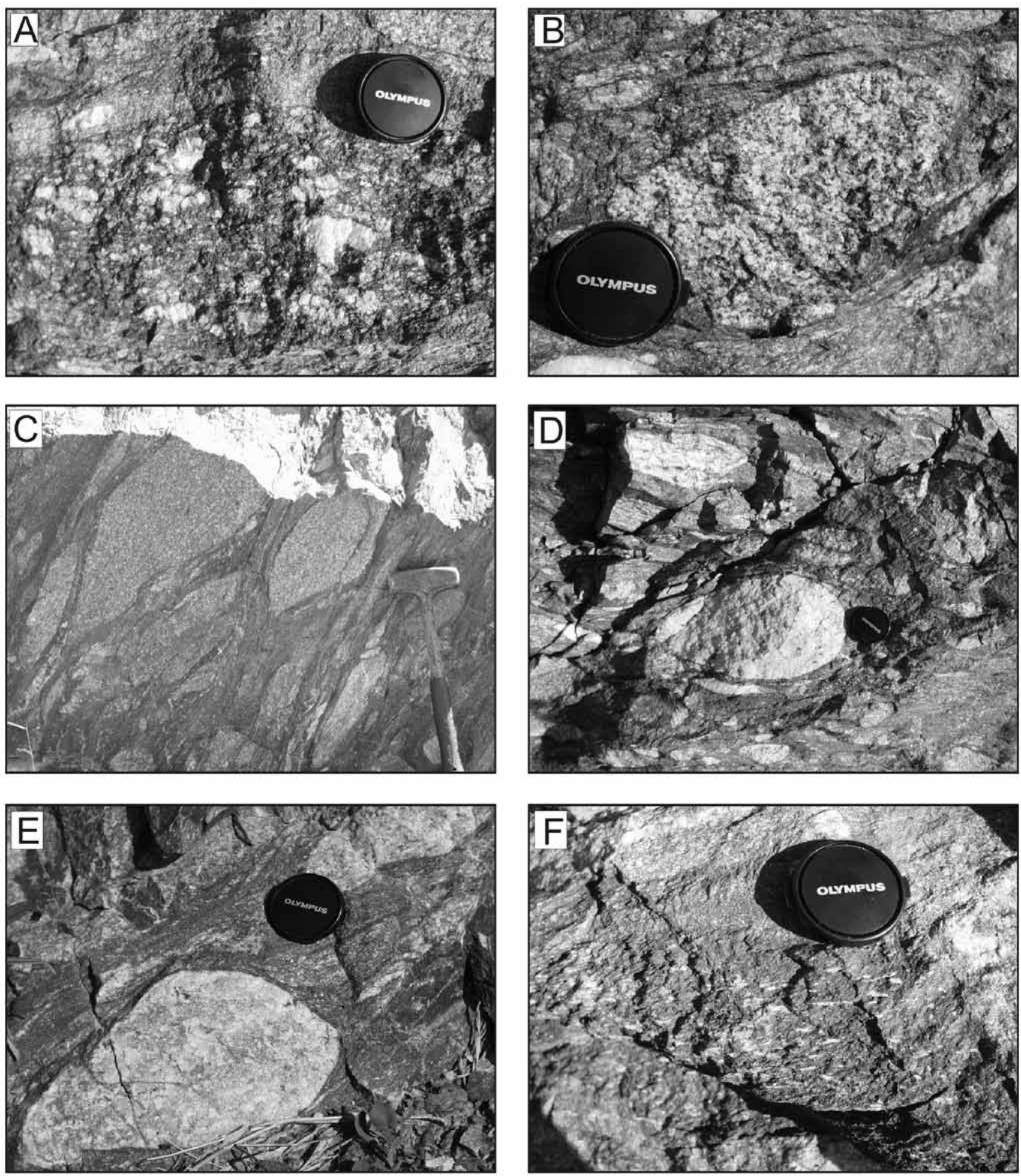

Figura 3 - Aspectos de campo dos diferentes litotipos de clastos dos metaconglomerados da Formação Morro Doce: A-Biotita Monzogranito Porfirítico; B-Monzogranito Inequigranular; C-Monzogranito Equigranular; D- Leucogranito Inequigranular; E- Quartzito; F- Rocha Metabásica.

corpo anfibolítico do Jaraguá (Ponto MD-43) tem foliação metamórfica incipiente, e apresenta mineralogia à base de hornblenda, plagioclásio, epidoto e titanita.

$\mathrm{Na}$ região do Morro do Polvilho ocorrem rochas metavulcânicas ácidas (Ponto MD-06 - Fig. 2A) que se intercalam com metarcóseos e metaconglome- rados, e foram designadas por Carneiro et al. (1984) como "meta-riodacitos". Com base na sua composição química (Le Bas et al. 1986), elas são reclassificadas neste trabalho como meta-traquidacitos e meta-riolitos porfiríticos (Fig. 4). Essas rochas têm fenocristais $(0,5$ $-1,0 \mathrm{~cm}$ ) de plagioclásio sódico (oligoclásio) que ape- 
sar da deformação, responsável pela geração de sombras de pressão, ainda preservam as características de cristais magmáticos (e.g., caráter subidiomórfico).

A susceptibilidade magnética das rochas metavulcânicas ácidas alcança valores muito elevados $\left(\mathrm{K}=100 \times 10^{-3} \mathrm{SI}\right)$, refletindo a grande quantidade de magnetita; esses valores tendem a diminuir próximo ao contato com os metaconglomerados, mas mantém-se tipicamente muito elevados e contrastados com os dos metarcóseos (e.g., $\mathrm{K}=45 \times 10^{-3}$ SI - Ponto MD-10).

Rochas metavulcânicas básicas amigdaloidais ocorrem preferencialmente como pequenos corpos dentro da unidade de metarcóseos (Ponto MD-39). Estas podem ocorrer na forma de dique cortando a unidade metaconglomerática na região do Morro Doce (Fig. 2B - Ponto MD-01), onde a deformação e recristalização metamórfica apagaram por completo a textura original do protólito ígneo. Em outra ocorrência estudada (Ponto MD-39), são comuns amígdalas estiradas que variam de 0,5 a $3 \mathrm{~cm}$ em uma matriz fina composta por epidoto, biotita, quartzo e plagioclásio granoblásticos, e minerais opacos.

\section{GEOQUÍMICA DOS CLASTOS GRANÍTICOS, METARCÓSEOS E ROCHAS METAVULCÂNI-}

CAS Os seixos graníticos predominantes têm características metaluminosas a fracamente peraluminosas, são ricos em $\mathrm{SiO}_{2}(65-78 \%)$, e têm $\mathrm{mg} \#=25-35$. As razões $\mathrm{A} / \mathrm{CNK}$ originais devem ter sido em geral menores que 1 , como indicado pela presença característica de minerais acessórios cálcicos como titanita e allanita. Entretanto, o caráter metaluminoso de alguns seixos mais afetados por alteração hidrotermal foi exagerado pela introdução de calcita secundária.

Diagramas de variação usando sílica como índice de diferenciação mostram tendências lineares de correlação negativa com $\mathrm{Na}_{2} \mathrm{O}, \mathrm{MgO}, \mathrm{CaO}, \mathrm{Fe}_{2} \mathrm{O}_{3}$, $\mathrm{TiO}_{2}$ e $\mathrm{P}_{2} \mathrm{O}_{5}$, compatíveis com a evolução de uma suite comagmática. Observa-se uma correlação negativa entre mg\# e $\mathrm{SiO}_{2}$, de forma que os seixos de biotita monzogranito porfirítico com maior IC, representaria um membro mais primitivo da suíte (Fig. 5 - dados na tabela 1).

A maioria dos elementos traço, como $\mathrm{Ba}, \mathrm{Sr}, \mathrm{V}$, $\mathrm{Zr}$ e Ga, mostra tendência de diminuição a partir de seixos graníticos menos diferenciados. Outros, como $\mathrm{Ce}, \mathrm{Y}$ e Th, mostram variação distinta, onde os teores são mais baixos no granito porfirítico, atingem valores máximos nos seixos graníticos inequigranulares e equigranulares, e diminuem nos leucogranitos inequigranulares. (Fig. 6 - dados na tabela 1).

Os padrões de elementos de terras raras mostram pequeno aumento em ETR leves, como indicado pelo maior fracionamento $\left(\mathrm{La}_{\mathrm{N}} / \mathrm{Yb}_{\mathrm{N}}=23-43\right)$ nas variedades equi e inequigranulares em relação à variedade mais primitiva porfirítica $\left(\mathrm{La}_{\mathrm{N}} / \mathrm{Yb}_{\mathrm{N}}=17\right)$. Em contrapartida, o seixo de leucogranito apresenta padrão pouco fracionado, com forte enriquecimento em ETR pesados $\left(\mathrm{La}_{\mathrm{N}} / \mathrm{Yb}_{\mathrm{N}}=5\right)$, característico de rochas graníticas mui-

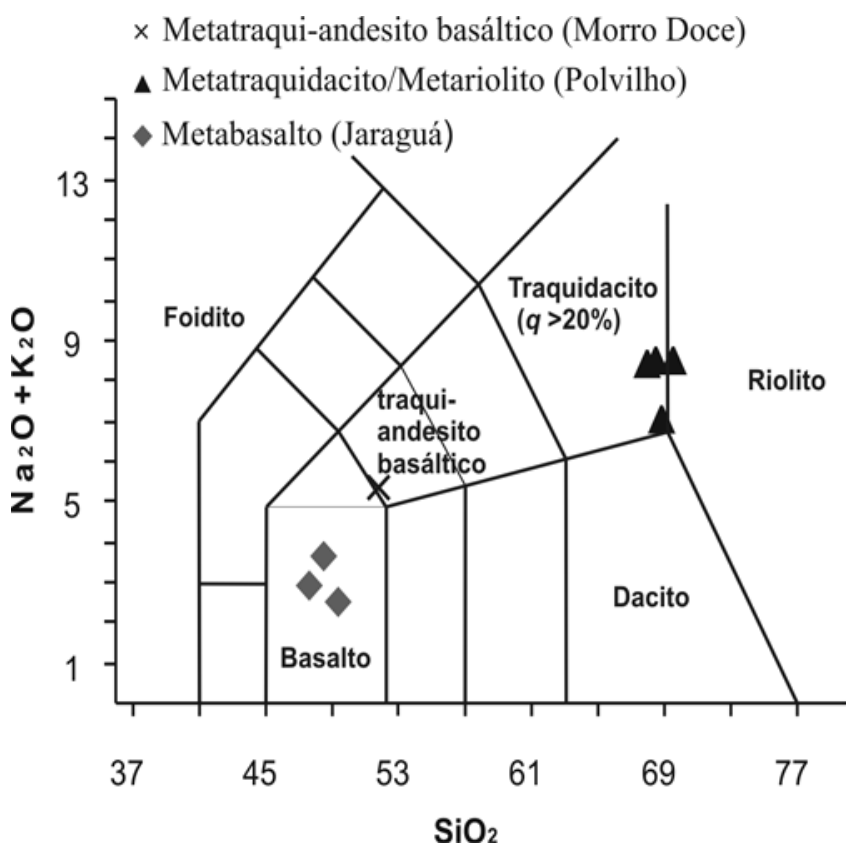

Figura 4 - Classificação química (Le Bas et al. 1986) das rochas metavulcânicas da Formação Morro Doce.

to diferenciadas. Todas as variedades apresentam leve anomalia negativa de $\mathrm{Eu}\left(\mathrm{Eu} / \mathrm{Eu}^{*}=0,46\right.$ e 0,64$)$, com exceção das amostras de monzogranito inequigranular (MD - 25A) e leucogranito inequigranular coletadas na região da Fazenda Ithayê (Fig. 7A - dados na tabela 3).

O padrão de elementos terras-raras do metarcóseo é, em linhas gerais, semelhante à média dos clastos, com razão $\mathrm{La}_{\mathrm{N}} / \mathrm{Yb}_{\mathrm{N}}=12$, mas apresenta anomalia negativa de Eu pouco expressiva $\left(\mathrm{Eu} / \mathrm{Eu}^{*}=0,82\right)$, o que sugere a contribuição de fontes adicionais. Fontes ígneas de caráter máfico parecem ter tido um papel importante durante a sedimentação dos metarcóseos, como mostram as razões $\mathrm{Cr} / \mathrm{Th}$, Ti/Zr e Co/Th (Fig. 7B), mas a assinatura de ETR do clasto de rocha metabásica analisado não poderia responder pelo comportamento do $\mathrm{Eu}$, pois tem anomalia fortemente negativa $\left(\mathrm{Eu} / \mathrm{Eu}^{*}=0,48\right)$.

Os meta-traquidacitos e metariolitos, quando comparados aos metarcóseos, formam um grupo quimicamente coeso (e.g., intervalo de $\mathrm{SiO}_{2}$ entre 67 e $68 \%$, enquanto nos metarcóseos este intervalo é de 69 e $76 \%$ ). Altos teores de $\mathrm{Fe}_{2} \mathrm{O}_{3}(7-5 \%)$, baixo $\mathrm{P}_{2} \mathrm{O}_{5}(0,08-$ $0,13 \%)$ e $\mathrm{mg} \#=(19-23)$ também diferenciam as rochas metavulcânicas ácidas dos metarcóseos, que acompanham o espalhamento dos clastos de granito dos metaconglomerados. São menores também os valores de perda ao fogo nas rochas metavulcânicas ácidas (Fig. 5 - dados na tabela 2).

As rochas metavulcânicas básicas amigdaloidais (meta-traquiandesitos basálticos) que ocorrem intercaladas no pacote metarcoseano diferem petrograficamente dos anfibolitos regionais (ex: corpo anfibolítico do Jaraguá). Estas diferenças são confirmadas pela geoquímica, que mostra teores mais ele- 

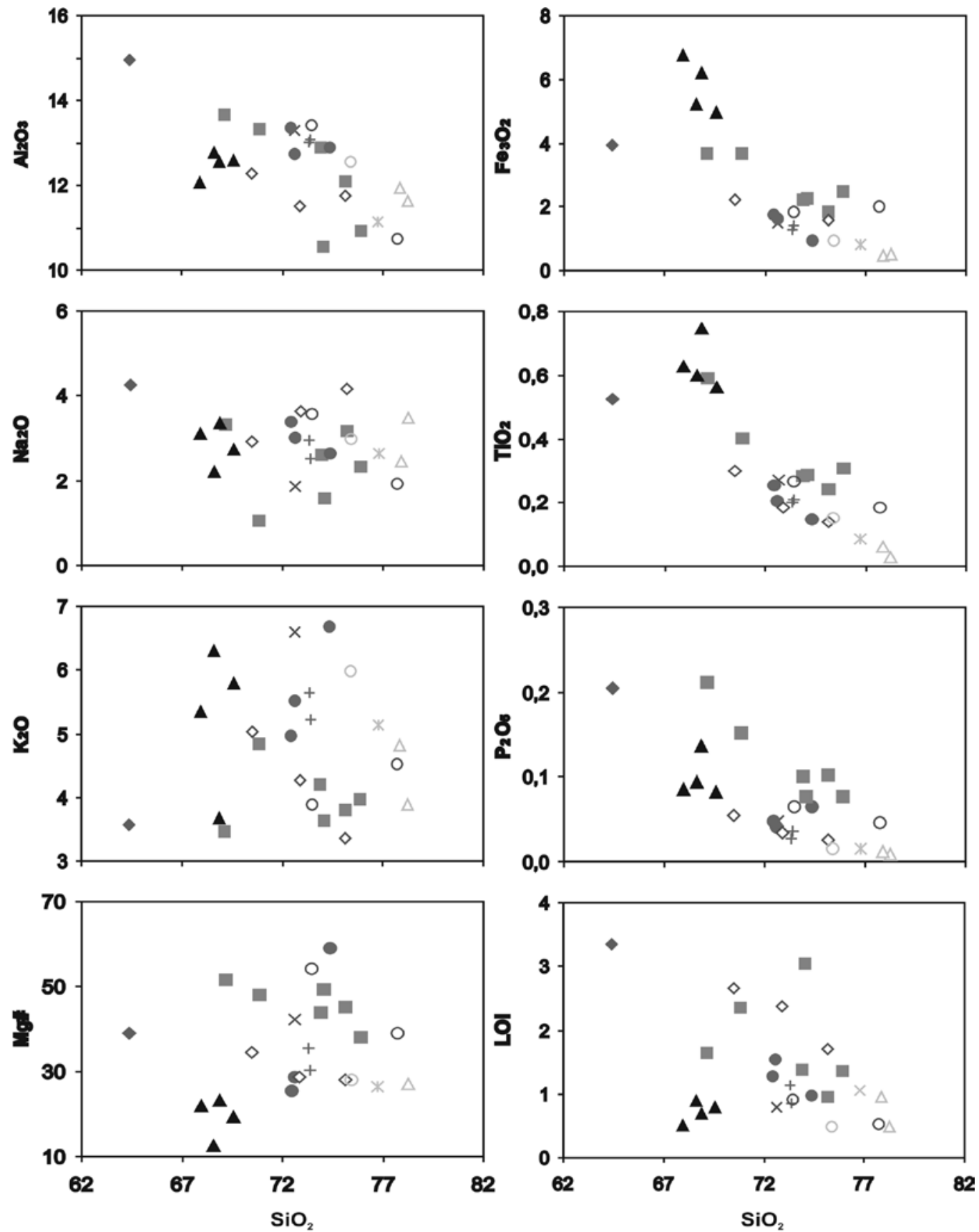

$\diamond$ Seixo de Monzogranito Inequigranular (Morro Doce) $\times$ Seixo de Monzogranito Inequigranular (Morro do Polvilho) - Seixo de Monzogranito Equigranular (Morro Doce) + Seixo de Monzogranito Equigranular (Morro do Polvilho)

* Seixo de Leucogranito Inequigranular (Morro Doce) $\triangle$ Seixo de Leucogranito Inequigranular (Morro do Polvilho)

- Seixo de Monzogranito Porfirítico (Morro Doce) o Seixo de Monzogranito Inequigranular (Fazenda Ithayê)

- Metarcoseo A Metatraquidacito/Metariolito $\quad$ Seixo de Leucogranito Inequigranular (Fazenda Ithayê)

Figura 5 - Diagramas de variação (elementos maiores) para rochas da Formação Morro Doce utilizando $\mathrm{SiO}_{2}$ como índice de diferenciação.

vados de $\mathrm{P}_{2} \mathrm{O}_{5}, \mathrm{TiO}_{2}, \mathrm{~K}_{2} \mathrm{O}, \mathrm{Ba}, \mathrm{Sr}, \mathrm{Zn}, \mathrm{Ce}$ e $\mathrm{Y}$ com relação aos anfibolitos, que por sua vez apresentam mais alto $\mathrm{CaO}$. (Fig. 8 - dados na tabela 2).

A assinatura das rochas metavulcânicas ácidas é típica de magmatismo intraplaca (Fig. 10), com destaque para o baixo mg\#, altos teores de HFSE (em especial $\mathrm{Zr}$ e Hf), e altos teores de LILE (Rb, Ba, Th e U), contrastados com baixo $\mathrm{Sr}$ (70-120 ppm), além de baixas razões $\mathrm{Cr} / \mathrm{Th}$ e Al/Ti (Figs. 9A, B, C, D). Tais características as aproximam das metavulcânicas ácidas Rio dos Remédios que ocorrem na base do Supergrupo Espinhaço, Chapada Diamantina (McReath et al. 1981).

A amostra de meta-traquiandesito basáltico (Ponto MD-39, Fig. 4) com elevados teores de $\mathrm{K}_{2} \mathrm{O}$ e outros elementos litófilos, tem teores relativamente altos de LILE (Rb, Ba e U), HFSE ( $\mathrm{Zr}$ e $\mathrm{Nb}$ ), e altas razões $\mathrm{La} / \mathrm{Sc}, \mathrm{Zr} / \mathrm{Y}$. Estas características, somadas ao padrão mais fracionado, com enriqueci- 

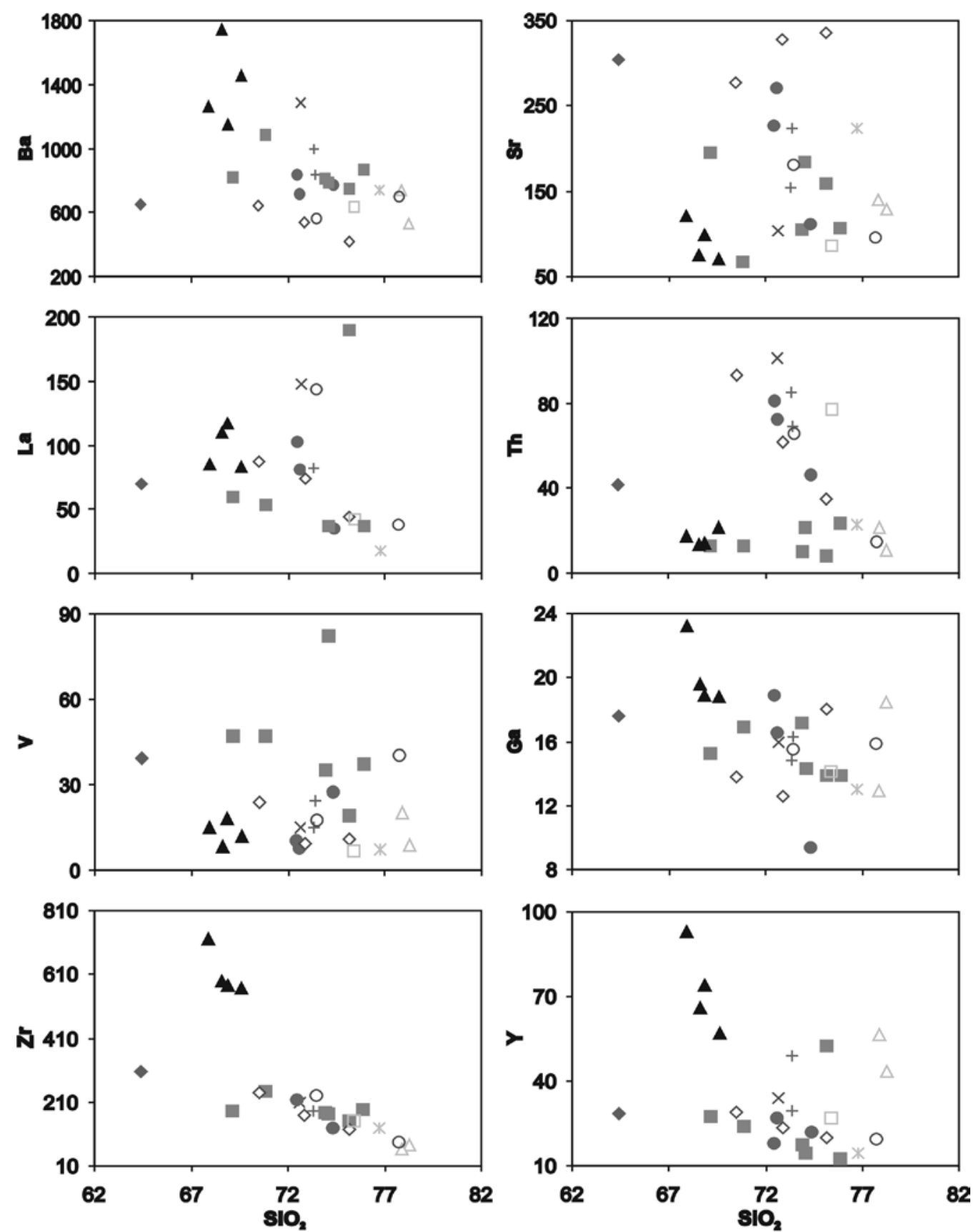

\footnotetext{
$\diamond$ Seixo de Monzogranito Inequigranular (Morro Doce) $\times$ Seixo de Monzogranito Inequigranular (Morro do Polvilho) - Seixo de Monzogranito Equigranular (Morro Doce) + Seixo de Monzogranito Equigranular (Morro do Polvilho) * Seixo de Leucogranito Inequigranular (Morro Doce) $\triangle$ Seixo de Leucogranito Inequigranular (Morro do Polvilho) ४ Seixo de Monzogranito Porfirítico (Morro Doce) o Seixo de Monzogranito Inequigranular (Fazenda Ithayê) - Metarcoseo A Metatraquidacito/Metariolito - Seixo de Leucogranito Inequigranular (Fazenda Ithayê)
}

Figura 6 - Diagramas de variação (elementos traços) para rochas da Formação Morro Doce utilizando $\mathrm{SiO}_{2}$ como índice de diferenciação.

mento equivalente em ETR leves $\left(\mathrm{La}_{\mathrm{N}} / \mathrm{Yb}_{\mathrm{N}}=13\right)$, e anomalia negativa de $\mathrm{Eu}\left(\mathrm{Eu} / \mathrm{Eu}^{*}=0,74\right.$ nas metavulcânicas básicas e 0,59 nas ácidas), sugerem um magmatismo intraplaca de caráter bimodal para o vulcanismo associado à Formação Morro Doce.

Os anfibolitos do Jaraguá apresentam padrão de ETR pouco fracionado, com razão $\mathrm{La}_{\mathrm{N}} / \mathrm{Yb}_{\mathrm{N}}=1,6$ e $\mathrm{Eu} / \mathrm{Eu}^{*}=1,0$ (Fig. 9C - dados na tabela 3) e características geoquímicas de basaltos toleíticos, quando comparados aos dados de Irvine \& Baragar (1971) (Fig. 11C), mais próximas de magmatismo de fundo oceânico tipo MORB quando comparados aos dados de Pearce \& Cann (1973); Pearce \& Norry (1979); Vermeesh (2006) (Figs.11 A, B, D), com baixas concentrações de elementos incompatíveis como $\mathrm{Rb}, \mathrm{Nb}$ e Th. Nesse sentido, embora de idade ainda desconhecida, mostram semelhanças com as rochas metabásicas supracrustais (com estruturas tipo "pillow lava") 


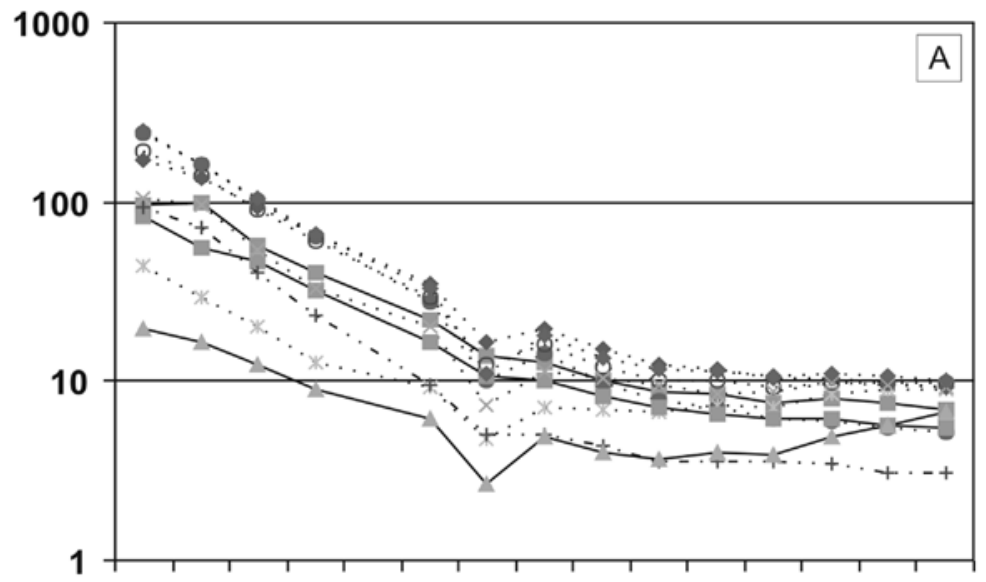

La Ce Pr Nd Sm Eu Gd Tb Dy Ho Er Tm Yb Lu

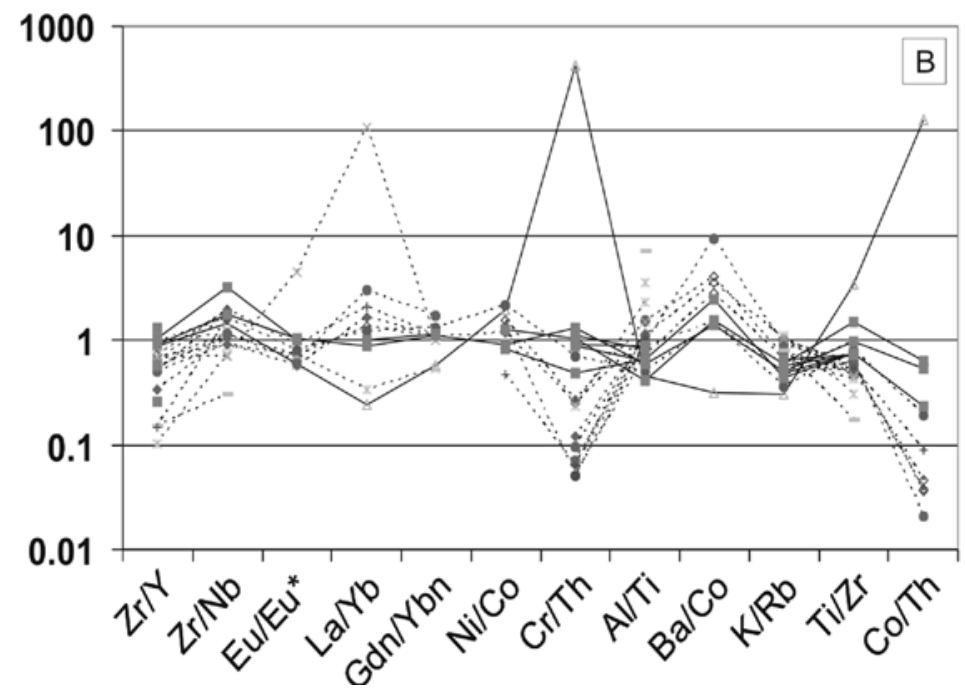

… Clasto de monzogranito equigranular - Região do Morro do Polvilho Clasto de leucogranito inequigranular - Região do Morro do Polvilho

•... Clasto de monzogranito inequigranular - Região do Morro do Polvilho

.+* Clasto de monzogranito inequigranular - Região da Fazenda Ithayê

Clasto de leucogranito inequigranular - Região da Fazenda Ithayê Clasto de rocha metabásica - Região do Morro Doce

... Clasto de monzogranito inequigranular - Região do Morro Doce

-... Clasto de monzogranito equigranular - Região do Morro Doce Clasto de leucogranito inequigranular - Região do Morro Doce

-.. Clasto de biotita monzogranito porfirítico - Região do Morro Doce

——- Metarcóseos da Formação Morro Doce

Figura 7 - (A) Padrões de elementos terras raras de clastos dos metaconglomerados e metarcóseos da Formação Morro Doce normalizados para o condrito (Taylor \& MacLennan 1985); (B) razões de clastos dos metaconglomerados e metarcóseos da Formação Morro Doce normalizadas pela média da crosta (Wedepohl 1995). 

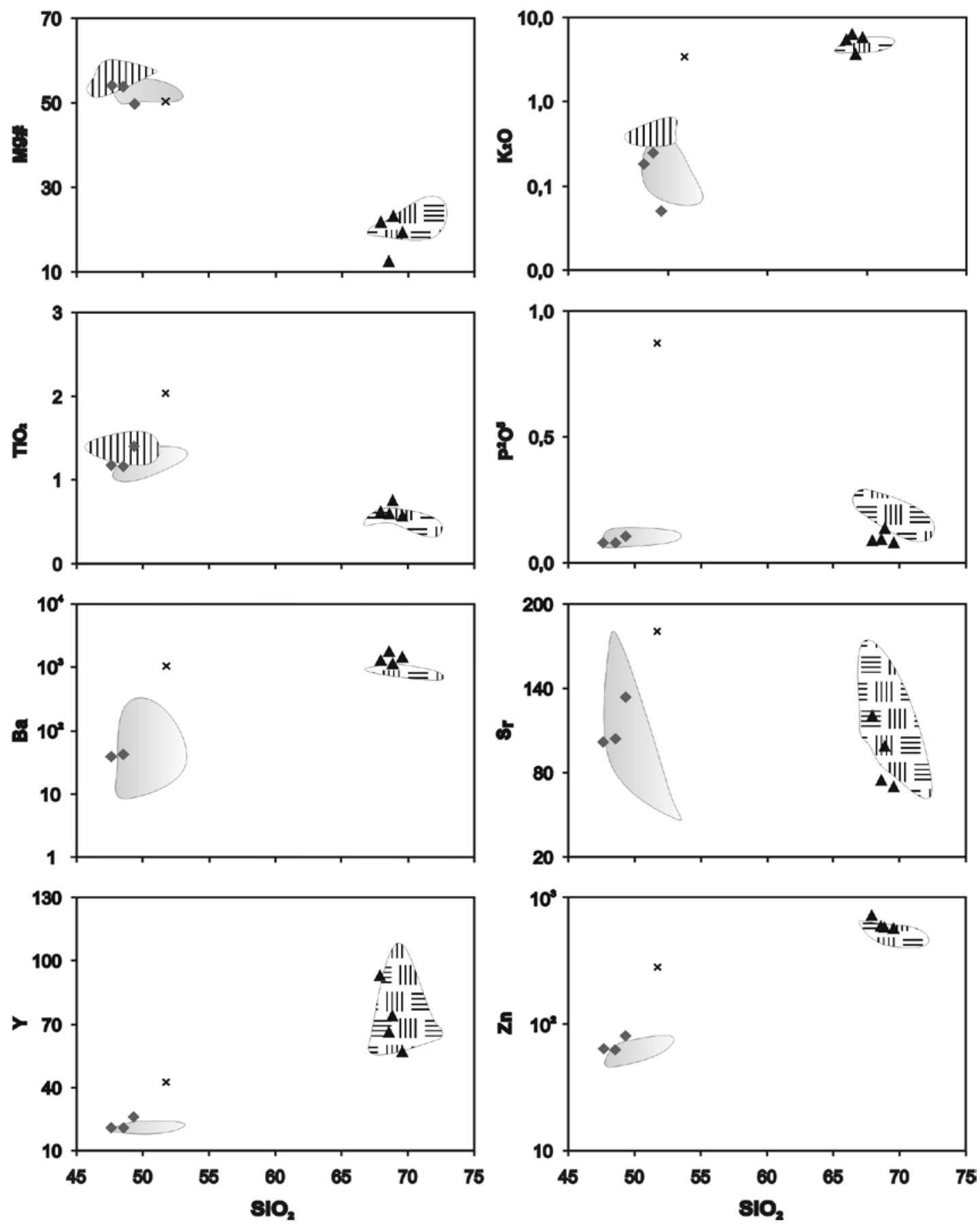

(I) Metavulcânicas Ácidas - Chapada Diamantina, Bahia (McReath, 1981) \ Metabasalto (Jaraguá)

Metabásicas - Pirapora, SP (Tassinari, 2001)

ム Metatraquidacito/Metariolito (Polvilho)

(III Metabásicas - Pirapora, SP (Lazzari, 1987)

$\times$ Metatraqui-andesito basáltico (Morro Doce)

Figura 8 - Diagramas de variação utilizando $\mathrm{SiO}$, como índice de diferenciação comparando as rochas metavulcânicas com ocorrências estudadas por Lazzari (1987) e Tassinari et al. (2001).

da região de Pirapora do Bom Jesus (Lazzari 1987; Tassinari et al. 2001).

CONCLUSÕES O estudo petrográfico dos clastos graníticos do metaconglomerado do Grupo São Roque permitiu a identificação de quatro variedades petrográ- ficas: biotita monzogranito porfiritico, monzogranito inequigranular, monzogranito equigranular e leucogranito inequigranular. O caráter comagmático entre os clastos é sugerido pelo alinhamento em uma mesma tendência, com diminuição nos teores de $\mathrm{Na}_{2} \mathrm{O}, \mathrm{MgO}$, $\mathrm{CaO}, \mathrm{Fe}_{2} \mathrm{O}_{3}, \mathrm{TiO}_{2}$ e $\mathrm{P}_{2} \mathrm{O}_{5}$ com o aumento da sílica, refle- 

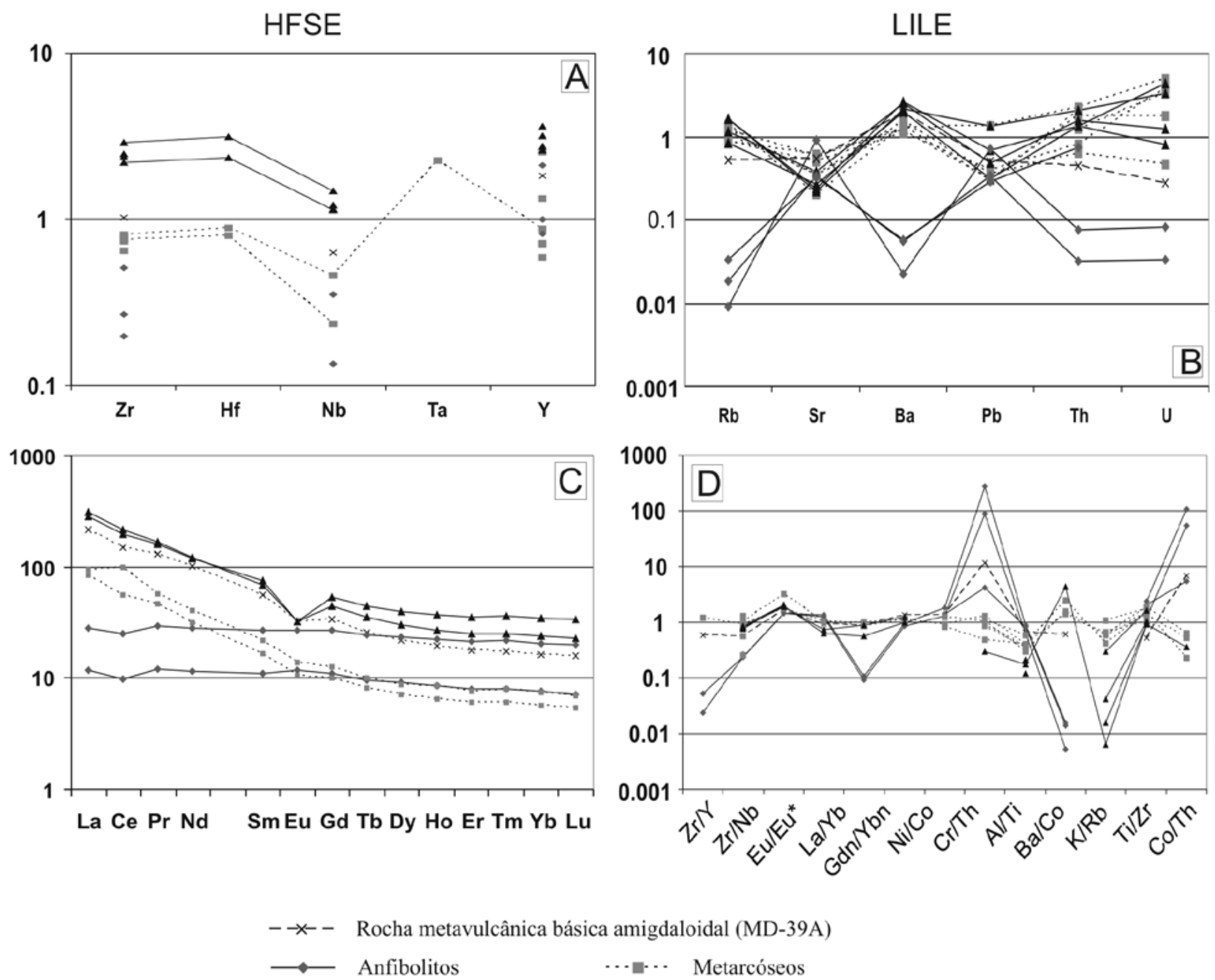

¿_ Metavulcânicas ácidas

Figura 9 - Comparação geoquímica entre rochas metavulcânicas e metarcóseos da Formação Morro Doce. (A)- HFSE normalizados pela média da crosta (Wedepohl 1995); (B) LILE normalizados pela média da crosta (Wedepohl 1995); (C) ETR normalizados por valores condríticos (Taylor \& MacLennan 1985); (D) razões normalizadas pela média da crosta (Wedepohl 1995).

tindo a tendência normal de diferenciação em magmas graníticos. Existe uma correlação negativa entre mg\# e $\mathrm{SiO}_{2}$, de forma que quanto mais félsico é o seixo (leucogranito inequigranular), menor é o mg\#. Portanto, a variedade biotita monzogranito porfirítico com maior IC representaria um membro mais primitivo com relação à evolução magmática dos magmas parentais.

De características metaluminosas a fracamente peraluminosas, os seixos graníticos predominantes são ricos em $\mathrm{SiO}_{2}(65-78 \%)$, e têm $\mathrm{mg} \#=25-35$. As razões $\mathrm{A} / \mathrm{CNK}$ originais devem ter sido em geral menores que 1, como indicado pela presença característica de minerais acessórios cálcicos como titanita e allanita. Entretanto, o caráter metaluminoso de alguns seixos mais afetados por alteração hidrotermal foi exagerado pela introdução de calcita secundária.

Os metarcóseos diferenciam-se das rochas metavulcânicas ácidas por apresentarem petrotrama sedimentar composta predominantemente por feldspatos detríticos sub-angulosos e geoquímica que acompanha o espalhamento dos clastos dos metaconglomerados aos quais estão associados. São diferentes também os valores de susceptibilidade magnética, notavelmente mais elevados nas metavulcânicas ácidas $\left(\mathrm{K}=40-100 \times 10^{-3}\right.$ SI), quando comparados aos metarcóseos $\left(0,2 \times 10^{-3}\right.$ SI). Portanto, conclui-se que a idade U-Pb em zircão de $1790 \pm 14$ Ma obtida por van Schumus et al. (1986) representa a idade de cristalização das rochas metavulcânicas ácidas, e não a idade da área fonte do Grupo São Roque, como proposto por Juliani et al. (1997).

Os meta-traquidacitos e meta-riolitos apresentam geoquímica típica de magmatismo intraplaca (Pearce et al. 1979), em especial baixo mg\#, altos teores de HFSE, em especial Zr, Hf, e altos teores de LILE (Rb, $\mathrm{Ba}$, Th e U), além do baixo $\mathrm{Sr}$ (70-120 ppm), e de baixas razões $\mathrm{Cr} / \mathrm{Th}$ e $\mathrm{Al} / \mathrm{Ti}$. É interessante notar que essas feições são similares às das rochas metavulcânicas ácidas Rio dos Remédios, que ocorrem na base do Supergrupo 

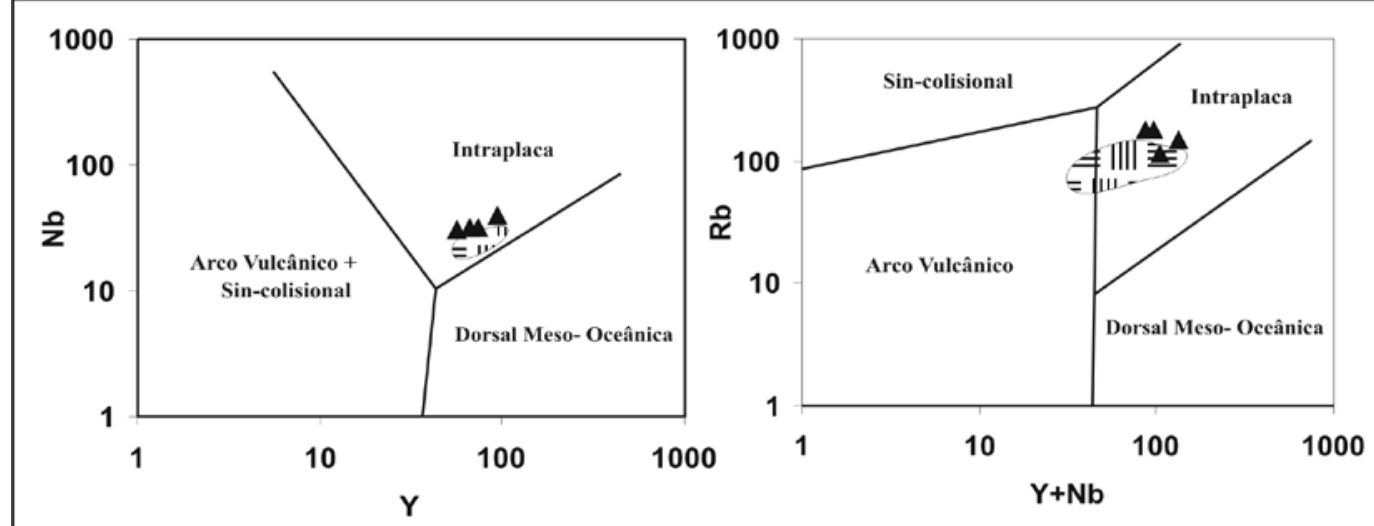

(1) Metavulcanicas Ácidas - Chapada Diamantina, Bahia (McReath et al., 1981)

$\Delta$ Meta-traquidacito/Metariolito (Morro do Polvilho)

Figura 10 - Diagrama $(N b \times Y)$ e (Rb $\times Y+N b)$ (Pearce et al. 1984) para rochas metavulcânicas ácidas da região do Morro do Polvilho.
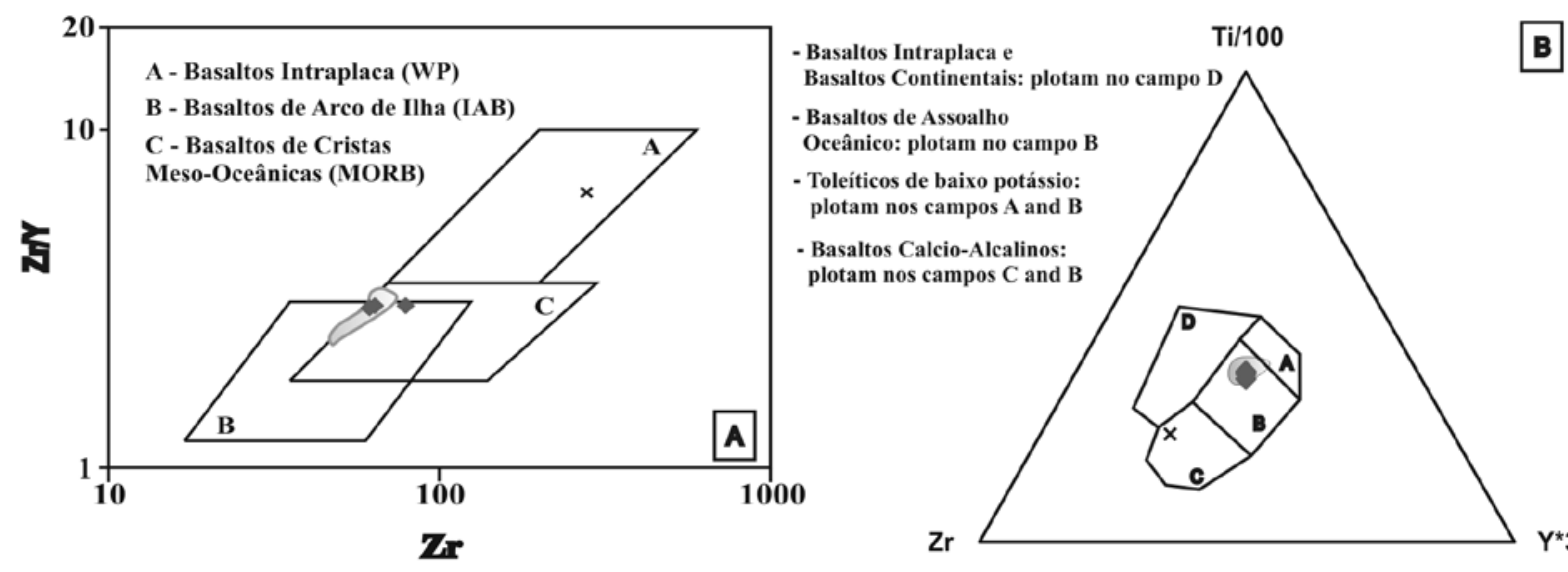

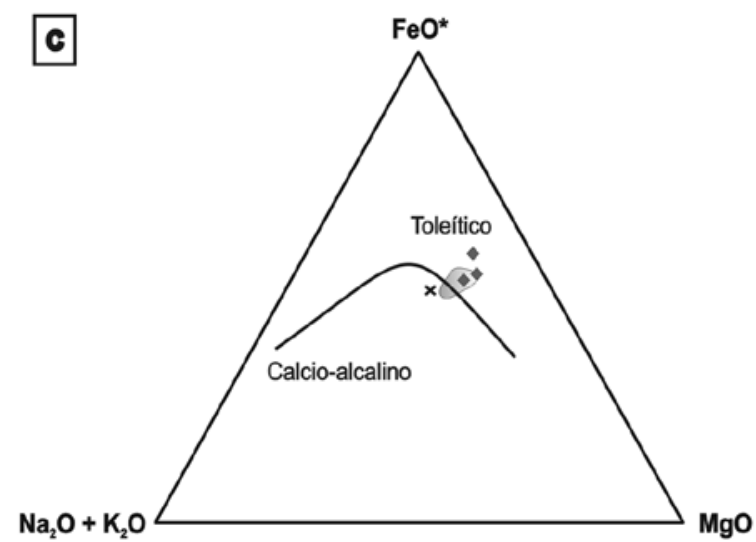

Metabasicas - Piarapora, SP (Tassinari, 2001)

$\times$ Metatraqui-andesito basáltico (Morro Doce)

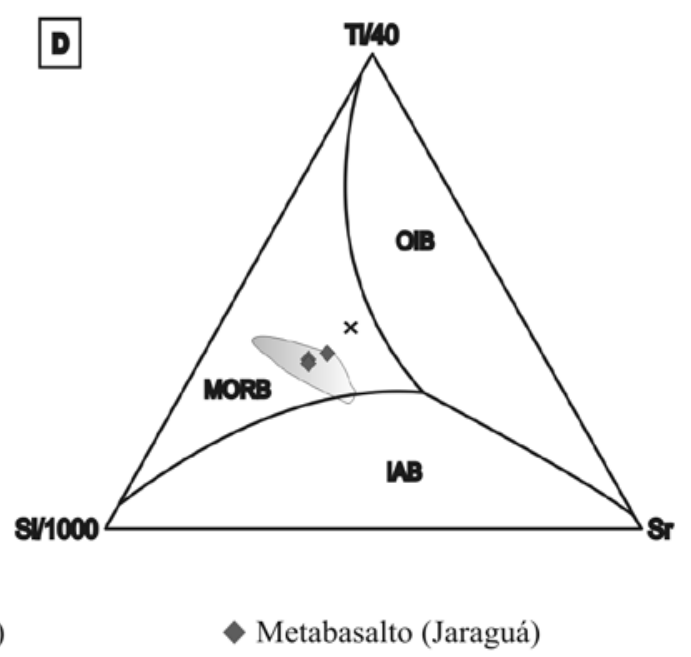

\ Metatraquidacito/Metariolito (Polvilho)

Figura 11 - Diagramas de discriminação tectônica para rochas metavulcânicas da região do Pico do Jaraguá e Morro Doce. A - Diagrama (Zr/Y x Zr) (Pearce \& Norry 1979); B - Diagrama (Ti/100 x $\left.\operatorname{Zr} \times Y^{*} 3\right)$ (Pearce \& Cann 1973); C - Diagrama AFM (Irvine \& Baragar 1971); D Diagrama (Ti/40 x Sr x Si/1000) (Vermeesh 2006). 
Tabela 1 - Análises químicas de seixos graníticos da Formação Morro Doce obtidas por FRX. smp = biotita monzogranito porfirítico; smi = monzogranito inequigranular; sme = monzogranito equigranular; sli = leucogranito inequigranular.

\begin{tabular}{|c|c|c|c|c|c|c|c|c|c|c|c|c|c|c|c|c|}
\hline & $\begin{array}{c}\mathrm{MD} \\
01 \mathrm{~N}\end{array}$ & $\begin{array}{c}\mathrm{MD} \\
01 \mathrm{E}\end{array}$ & $\begin{array}{l}\mathrm{MD} \\
01 \mathrm{~F}\end{array}$ & $\begin{array}{l}\text { MD } \\
01 \text { I }\end{array}$ & $\begin{array}{c}\text { MD- } \\
25 \mathrm{a}\end{array}$ & $\begin{array}{c}\text { MD- } \\
34 \mathrm{a}\end{array}$ & $\begin{array}{l}\text { MD- } \\
07 \mathrm{~A}\end{array}$ & $\begin{array}{c}\text { MD } \\
01 \mathrm{C}\end{array}$ & $\begin{array}{c}\mathrm{MD} \\
01 \mathrm{H}\end{array}$ & $\begin{array}{l}\text { MD } \\
03 \mathrm{~B}\end{array}$ & $\begin{array}{c}\text { MD- } \\
11 \mathrm{~B}\end{array}$ & $\begin{array}{l}\text { MD- } \\
10 \mathrm{~B}\end{array}$ & $\begin{array}{c}\text { MD- } \\
26 \mathrm{a}\end{array}$ & $\begin{array}{l}\mathrm{MD} \\
01 \mathrm{D}\end{array}$ & $\begin{array}{l}\text { MD- } \\
10 \mathrm{~A}\end{array}$ & $\begin{array}{c}\text { MD- } \\
11 \mathrm{~A}\end{array}$ \\
\hline & $s m p$ & smi & smi & smi & smi & smi & smi & sme & sme & sme & sme & sme & sli & $s l i$ & sli & sli \\
\hline $\mathrm{SiO}_{2}$ & 64.40 & 72.87 & 75.16 & 70.49 & 77.71 & 73.46 & 72.58 & 72.45 & 72.60 & 74.35 & 73.20 & 73.33 & 75.40 & 76.76 & 78.26 & 77.87 \\
\hline $\mathrm{Al}_{2} \mathrm{O}_{2}$ & 14.95 & 11.50 & 11.74 & 12.28 & 10.73 & 13.41 & 13.29 & 13.36 & 12.73 & 12.89 & 13.00 & 13.01 & 12.56 & 11.13 & 11.63 & 11.93 \\
\hline $\mathrm{MnO}$ & 0.067 & 0.044 & 0.036 & 0.048 & 0.019 & 0.024 & 0.027 & 0.025 & 0.028 & 0.018 & 0.022 & 0.023 & 0.010 & 0.024 & 0.014 & 0.012 \\
\hline $\mathrm{MgO}$ & 1.28 & 0.29 & 0.31 & 0.60 & 0.65 & 1.09 & 0.55 & 0.30 & 0.33 & 0.68 & 0.29 & 0.36 & 0.18 & 0.15 & 0.10 & 0.59 \\
\hline $\mathrm{CaO}$ & 3.58 & 2.77 & 1.73 & 2.83 & 0.80 & 0.48 & 1.72 & 1.03 & 1.12 & 0.59 & 2.03 & 1.34 & 0.38 & 0.84 & 0.87 & 1.59 \\
\hline $\mathrm{Na}_{2} \mathrm{O}$ & 4.25 & 3.64 & 4.16 & 2.93 & 1.93 & 3.56 & 1.88 & 3.38 & 3.02 & 2.63 & 2.48 & 2.95 & 3.00 & 2.64 & 3.47 & 2.45 \\
\hline $\mathrm{K}_{2} \mathrm{O}$ & 3.57 & 4.27 & 3.35 & 5.03 & 4.52 & 3.88 & 6.59 & 4.97 & 5.52 & 6.68 & 5.23 & 5.65 & 5.99 & 5.14 & 3.89 & 4.81 \\
\hline $\mathrm{TiO}_{2}$ & 0.525 & 0.185 & 0.140 & 0.299 & 0.184 & 0.268 & 0.270 & 0.256 & 0.207 & 0.147 & 0.217 & 0.200 & 0.150 & 0.087 & 0.029 & 0.060 \\
\hline $\mathrm{P}_{2} \mathrm{O}_{5}$ & 0.204 & 0.034 & 0.025 & 0.054 & 0.046 & 0.064 & 0.048 & 0.048 & 0.041 & 0.064 & 0.032 & 0.027 & 0.016 & 0.015 & 0.005 & 0.012 \\
\hline $\mathrm{Fe}_{2}$ & 3.95 & 1.42 & 1.57 & 2.24 & 2.01 & 1.82 & 1.48 & 1.75 & 1.62 & 0.94 & 1.41 & 1.29 & 0.92 & 0.83 & 0.53 & 0.46 \\
\hline P.F. & 3.35 & 2.38 & 1.70 & 2.66 & 0.53 & 0.92 & 0.79 & 1.27 & 1.55 & 0.98 & 0.86 & 1.14 & 0.48 & 1.06 & 0.48 & 0.96 \\
\hline Total & 100.13 & 99.40 & 99.92 & 99.46 & 99.13 & 98.98 & 99.23 & 98.84 & 98.77 & 99.97 & 98.77 & 99.32 & 99.09 & 98.68 & 99.28 & 100.74 \\
\hline $\mathrm{Ba}$ & 647 & 539 & 416 & 645 & 701 & 565 & 1286 & 833 & 711 & 769 & 827 & 993 & 636 & 738 & 528 & 735 \\
\hline $\mathrm{Ce}$ & 123 & 118 & 66 & 157 & 61 & 62 & 139 & 172 & 144 & $<35$ & 87 & 102 & 76 & 32 & $<35$ & $<35$ \\
\hline $\mathrm{Cr}$ & 83 & 51 & 32 & 16 & $<13$ & 15 & 18 & 17 & 23 & $<13$ & 30 & 20 & $<13$ & 24 & $<13$ & $<13$ \\
\hline $\mathrm{Cu}$ & 29 & 41 & 32 & 20 & 7 & 19 & 35 & 45 & 38 & 40 & 17 & 104 & 7 & 44 & 34 & 5 \\
\hline $\mathrm{Ga}$ & 18 & 13 & 18 & 14 & 16 & 16 & 16 & 19 & 17 & 9 & 17 & 15 & 14 & 13 & 19 & 13 \\
\hline $\mathrm{La}$ & 69 & 74 & 45 & 87 & 38 & 144 & 148 & 102 & 81 & 35 & 71 & 82 & 43 & 18 & $<28$ & $<28$ \\
\hline $\mathrm{Nb}$ & 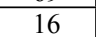 & 15 & 13 & 14 & $<9$ & 16 & $<9$ & 20 & 19 & 8 & 18 & 17 & 24 & 14 & 27 & 10 \\
\hline $\mathrm{Nd}$ & 48 & 43 & 34 & 34 & $<14$ & 59 & 60 & 63 & 41 & $<14$ & 36 & 42 & 21 & 25 & $<14$ & 26 \\
\hline $\mathrm{Ni}$ & 26 & 5 & 5 & 9 & $<5$ & 5 & $<5$ & $<5$ & $<5$ & 5 & $<5$ & $<5$ & $<5$ & $<5$ & $<5$ & $<5$ \\
\hline $\mathrm{Pb}$ & 31 & 40 & 14 & 21 & 33 & 20 & 19 & 26 & 20 & 40 & 30 & 29 & 22 & 24 & 21 & 26 \\
\hline $\mathrm{Rb}$ & 156 & 73 & 77 & 123 & 151 & 129 & 194 & 101 & 113 & 113 & 143 & 112 & 99 & 79 & 78 & 119 \\
\hline $\mathrm{Sr}$ & 305 & 328 & 336 & 277 & 96 & 181 & 104 & 227 & 271 & 112 & 222 & 155 & 86 & 224 & 128 & 141 \\
\hline Th & 41 & 62 & 35 & 93 & 15 & 66 & 101 & 81 & 72 & 46 & 72 & 85 & 77 & 23 & 11 & 22 \\
\hline $\mathrm{U}$ & 8 & 7 & 7 & 9 & 12 & 15 & 10 & 9 & 8 & 9 & 14 & 16 & 19 & 7 & 7 & 7 \\
\hline $\mathrm{V}$ & 39 & 9 & 11 & 24 & 41 & 17 & 15 & 10 & 8 & 27 & 11 & 15 & 7 & 7 & 9 & 20 \\
\hline $\mathrm{Y}$ & 28 & 23 & 20 & 29 & 20 & 140 & 34 & 18 & 27 & 22 & 47 & 30 & 27 & 14 & 44 & 56 \\
\hline $\mathrm{Zn}$ & 62 & 22 & 17 & 50 & 28 & 17 & 17 & 19 & 17 & 16 & 12 & 17 & 8 & 7 & 7 & 5 \\
\hline $\mathrm{Zr}$ & 307 & 170 & 127 & 239 & 84 & 231 & 208 & 218 & 198 & 128 & 185 & 184 & 152 & 131 & 76 & 65 \\
\hline
\end{tabular}

Tabela 2 - Análises químicas de rochas metassedimentares (metarcóseos) e metavulcânicas da Formação Morro Doce obtidas por FRX. ma = metarcóseo; mva = rocha metavulcânica ácida; mvb = rocha metavulcânica básica; anfibolito.

\begin{tabular}{|c|c|c|c|c|c|c|c|c|c|c|c|c|c|c|}
\hline & MD-03a & MD-04a & MD-26b & MD-36 & MD-38 & MD $01 \mathrm{~B}$ & Т 327 & MD-06 & MD-08 & MD-09 & MD-39a & MD-43 & MD-46 & MD-47 \\
\hline & $m a$ & $m a$ & $m a$ & $m a$ & $m a$ & $m a$ & $m v a$ & $m v a$ & $m v a$ & $m v a$ & $m v b$ & anfibolito & anfibolito & anfibolito \\
\hline $\mathrm{SiO}_{2}$ & 74.07 & 73.91 & 75.89 & 75.16 & 69.14 & 70.85 & 69.59 & 67.92 & 68.59 & 68.87 & 51.74 & 49.35 & 47.65 & 48.55 \\
\hline $\mathrm{Al}_{2} \mathrm{O}_{3}$ & 10.55 & 12.90 & 10.92 & 12.09 & 13.65 & 13.31 & 12.57 & 12.07 & 12.77 & 12.56 & 13.85 & 13.80 & 13.86 & 14.04 \\
\hline $\mathrm{MnO}^{2}$ & 0.034 & 0.023 & 0.025 & 0.030 & 0.055 & 0.039 & 0.050 & 0.046 & 0.066 & 0.080 & 0.206 & 0.189 & 0.190 & 0.164 \\
\hline $\mathrm{MgO}$ & 1.11 & 0.88 & 0.78 & 0.76 & 1.98 & 1.70 & 0.60 & 0.95 & 0.38 & 0.95 & 6.43 & 6.97 & 8.13 & 7.54 \\
\hline $\mathrm{CaO}$ & 2.75 & 0.65 & 0.75 & 1.07 & 1.58 & 1.16 & 1.18 & 1.30 & 1.55 & 1.43 & 3.99 & 10.05 & 10.45 & 9.90 \\
\hline $\mathrm{Na}_{2} \mathrm{O}$ & 1.57 & 2.60 & 2.32 & 3.18 & 3.33 & 1.07 & 2.75 & 3.10 & 2.21 & 3.36 & 1.89 & 2.43 & 2.76 & 3.36 \\
\hline $\mathrm{K}_{2}^{2} \mathrm{O}$ & 3.63 & 4.20 & 3.98 & 3.80 & 3.47 & 4.85 & 5.79 & 5.35 & 6.31 & 3.68 & 3.43 & 0.05 & 0.18 & 0.25 \\
\hline $\mathrm{TiO}_{2}$ & 0.287 & 0.282 & 0.306 & 0.244 & 0.591 & 0.403 & 0.563 & 0.627 & 0.599 & 0.748 & 2.039 & 1.406 & 1.182 & 1.167 \\
\hline $\mathrm{P}_{2} \mathrm{O}_{5}$ & 0.077 & 0.100 & 0.077 & 0.103 & 0.212 & 0.152 & 0.081 & 0.086 & 0.093 & 0.136 & 0.873 & 0.106 & 0.081 & 0.079 \\
\hline $\mathrm{Fe}_{2} \mathrm{O}_{3}$ & 2.27 & 2.23 & 2.50 & 1.82 & 3.68 & 3.66 & 4.98 & 6.74 & 5.23 & 6.21 & 12.52 & 13.92 & 13.64 & 12.87 \\
\hline P.F. & 3.05 & 1.38 & 1.37 & 0.95 & 1.64 & 2.36 & 0.80 & 0.51 & 0.90 & 0.70 & 1.40 & 0.58 & 1.03 & 1.19 \\
\hline Total & 99.40 & 99.16 & 98.92 & 99.21 & 99.33 & 99.55 & 98.95 & 98.70 & 98.70 & 98.72 & 98.37 & 98.85 & 99.15 & 99.11 \\
\hline $\mathrm{Ba}$ & 787 & 814 & 864 & 749 & 821 & 1088 & 1454 & 1263 & 1744 & 1146 & 1036 & $<37$ & 39 & 42 \\
\hline $\mathrm{Ce}$ & 42 & 43 & 48 & $<35$ & 87 & 87 & 78 & 121 & 146 & 156 & 130 & 71 & 73 & 80 \\
\hline Co & 6 & $<6$ & $<6$ & $<6$ & 9 & 11 & $<6$ & 7 & & $<6$ & 36 & 48 & 48 & 41 \\
\hline $\mathrm{Cr}$ & 36 & 25 & 69 & 26 & 45 & 82 & $<13$ & 17 & $<13$ & $<13$ & 181 & 240 & 111 & 315 \\
\hline $\mathrm{Cu}$ & 20 & $<5$ & 13 & 9 & $<5$ & $<5$ & 7 & $<5$ & 17 & 25 & 172 & 220 & 81 & 94 \\
\hline $\mathrm{Ga}$ & 14 & 17 & 14 & 14 & 15 & 17 & 19 & 23 & 20 & 19 & 19 & 18 & 17 & 20 \\
\hline $\mathrm{La}$ & 37 & $<28$ & 37 & 189 & 59 & 53 & 83 & 85 & 109 & 117 & 64 & $<28$ & $<28$ & $<28$ \\
\hline $\mathrm{Nb}$ & $<9$ & $<9$ & $<9$ & $<9$ & $<<9$ & 12 & 30 & 39 & 32 & 32 & 15 & $<9$ & $<9$ & $<9$ \\
\hline $\mathrm{Nd}$ & 18 & 26 & 21 & 116 & 53 & 37 & 37 & 81 & 85 & 78 & 72 & 16 & 21 & 18 \\
\hline $\mathrm{Ni}$ & 7 & 10 & 12 & 11 & 19 & 16 & $<5$ & $<5$ & $<5$ & $<5$ & 78 & 102 & 108 & 120 \\
\hline $\mathrm{Pb}$ & 5 & $<4$ & 22 & $\frac{11}{7}$ & -1 & $<4$ & 22 & 7 & 12 & $<4$ & 12 & $\frac{102}{11}$ & $\frac{100}{5}$ & $\frac{120}{9}$ \\
\hline $\mathrm{Rb}$ & 131 & 124 & 130 & 94 & 95 & 172 & 182 & 150 & 182 & 114 & 68 & 3 & 4 & 4 \\
\hline $\mathrm{Sr}$ & 184 & 106 & 108 & 159 & 196 & 68 & 70 & 121 & 75 & 99 & 180 & 134 & 102 & 104 \\
\hline Th & 22 & 10 & 23 & 8 & 13 & 13 & 22 & 17 & 14 & 14 & 10 & 8 & 8 & 7 \\
\hline $\mathrm{U}$ & $<3$ & 13 & 13 & 10 & 8 & 9 & 8 & 12 & 11 & 8 & 3 & $<3$ & $<3$ & $<3$ \\
\hline $\mathrm{V}$ & 82 & 35 & 37 & 19 & 47 & 47 & 12 & 15 & 8 & 18 & 215 & 369 & 309 & 344 \\
\hline Y & 15 & 17 & 12 & 53 & 28 & 24 & 57 & 93 & 66 & 74 & 43 & 26 & 21 & 21 \\
\hline $\mathrm{Zn}$ & 30 & 9 & 34 & 8 & 66 & 70 & 51 & 54 & 49 & 76 & 160 & 106 & 101 & 138 \\
\hline $\mathrm{Zr}$ & 175 & 177 & 187 & 153 & 182 & 242 & 568 & 723 & 589 & 577 & 281 & 80 & 64 & 63 \\
\hline
\end{tabular}


Tabela 3 - Análises químicas de elementos traço em rochas da Formação Morro Doce obtidas por ICP-MS. smp = biotita monzogranito porfirítico; $s m i=$ monzogranito inequigranular; sme = monzogranito equigranular; sli = leucogranito inequigranular; $s m v b=$ seixo de rocha metavulcânica básica; $m a=$ metarcóseo; $m v a=$ rocha metavulcânica ácida; $m v b$ = rocha metavulcânica básica; anfibolito.

\begin{tabular}{|c|c|c|c|c|c|c|c|c|c|c|c|c|c|c|c|}
\hline & MD-01N & MD-01E & MD-25A & MD-01C & MD-10B & MD-01D & MD-26A & MD-01M & MD-01B & MD-04A & MD-06 & MD-09 & MD-39A & MD-43 & MD-47 \\
\hline & smp & smi & smi & sme & sme & sli & sli & smvb & ma & $\mathrm{ma}$ & mva & mva & mvb. & anfiboli & anfibol \\
\hline $\mathrm{Rb}$ & 159.40 & 66.14 & 142.55 & 90.98 & 97.41 & 72.86 & 92.13 & 326 & 154.50 & 117.79 & 125.57 & 93.88 & 57.54 & 0.99 & 2.05 \\
\hline $\mathrm{Sr}$ & 307.27 & 347.06 & 94.05 & 261.94 & 167.18 & 238.46 & 86.39 & 16 & .49 & 109.46 & 18.48 & 3.31 & 173.15 & 281.56 & 108.24 \\
\hline $\mathrm{Y}$ & 04 & 80 & 11.74 & .24 & 27.10 & 5.30 & 19.54 & 03 & .10 & 4.88 & 5.09 & 4.27 & 7.72 & 43.95 & 16.92 \\
\hline $\mathrm{Zr}$ & 298.25 & 149.81 & 84.82 & 182.28 & 189.67 & 131.31 & 149.89 & 90.0 & 191.29 & 180.06 & 689.81 & 520.04 & 244.13 & 121.37 & 47.02 \\
\hline $\mathrm{Nb}$ & 19.53 & 14.65 & 4.78 & 17.49 & 19.71 & 16.54 & 23.42 & 6.86 & 11.88 & 12 & 38.43 & 29.73 & 16.42 & .24 & 3.53 \\
\hline Cs & & 11 & 34 & 5 & 66 & & 28 & 31 & 2.37 & & 2.06 & 1.05 & 2.74 & 66 & 97 \\
\hline $\mathrm{Ba}$ & 622.48 & 518.06 & 874.32 & 913.96 & 902.34 & 751.89 & 807.23 & 7 & 888.09 & 1025.20 & 1666.75 & 1335.59 & \begin{tabular}{|l|}
1296.31 \\
\end{tabular} & 4.79 & 37.55 \\
\hline $\mathrm{La}$ & 11 & 69.75 & 34.15 & .66 & 92.30 & 15.97 & 38.71 & 7.24 & 35.07 & 30.78 & 104.83 & 114.89 & 79.34 & 30 & 4.34 \\
\hline $\mathrm{Ce}$ & 07 & 50 & 68.83 & 2.72 & 156.75 & 28.26 & 92.00 & $\pi$ & 94.45 & 16 & 189.94 & 205.28 & 143.57 & 93 & 52 \\
\hline $\operatorname{Pr}$ & 12.92 & 9 & 5.48 & 32 & 14.30 & 2.73 & 7.44 & 1.71 & 7.78 & 34 & 21.80 & 22.89 & 17.76 & 4.03 & 1.67 \\
\hline $\mathrm{Nd}$ & 25 & 60 & 16.66 & .25 & 7.65 & & 23.45 & 6. & 28.78 & 2.56 & 85.48 & 87.27 & 72.45 & 19.90 & 21 \\
\hline $\mathrm{Sm}$ & & & & & & & 4.62 & 1 & & 87 & 17.39 & 15.76 & 13.02 & 7 & 54 \\
\hline $\mathrm{Eu}$ & & & 0.44 & 0. & 7 & & 0.64 & 23 & 1. & 92 & 2.84 & 2.82 & 81 & 2.36 & .03 \\
\hline $\mathrm{Gd}$ & & & & & & & 47 & & & 08 & 16.34 & 13.58 & 10.45 & 0 & .37 \\
\hline $\mathrm{Tb}$ & & 70 & 5 & 7 & 8 & 0 & 0.60 & 0.24 & 0.58 & 8 & 2.56 & 2.06 & 1.50 & .41 & 56 \\
\hline Dy & & & 1 & 99 & 39 & & 3.59 & 39 & & 1 & 15.10 & 11.57 & 28 & 85 & 47 \\
\hline Но & & & & 0.61 & 66 & & 0.73 & & & 55 & 3.12 & 2.29 & 1.65 & 1.91 & 0.74 \\
\hline $\mathrm{Er}$ & 2 & 2.33 & 0 & 1.56 & 6 & 8 & 2.16 & 0.97 & 0 & 52 & .85 & 6.24 & 4.44 & 5.34 & 2.01 \\
\hline $\mathrm{Tm}$ & & & & & 0 & & 0.35 & o & & 2 & 1.30 & 0.89 & 0.62 & 0.77 & 0.29 \\
\hline $\mathrm{Yb}$ & & & 0.76 & & 62 & 2.22 & 2.38 & 年 & & 42 & 8.67 & 5.90 & 4.08 & 5.09 & 1.89 \\
\hline $\mathrm{Lu}$ & & & 0.12 & .20 & 0.39 & & 0.35 & 0.25 & 0.27 & 21 & 1.29 & 0.87 & 0.61 & 0.76 & 0.27 \\
\hline $\mathrm{Hf}$ & & & 2.43 & & 5.94 & & 4.84 & 23 & 5.18 & 4.66 & 18.18 & 13.61 & 6.78 & 4.31 & 1.67 \\
\hline $\mathrm{Ta}$ & 2.36 & 2.02 & & & 3.76 & & & 3.05 & 3.38 & & & & & & \\
\hline $\mathrm{Pb}$ & 36.45 & 44.46 & 30.72 & 22.43 & 40.03 & 27.37 & 23.75 & 19.9 & 5.20 & & & 5.35 & 8.66 & 12.16 & 5.85 \\
\hline $\mathrm{Th}$ & 35.20 & 61.37 & 16.73 & 71.73 & 90.15 & 30.09 & 83.78 & 0.34 & 18.27 & 58 & 16.27 & 14.07 & 4.65 & .79 & 0.33 \\
\hline $\mathrm{U}$ & 6.73 & 13.37 & 1.16 & 14.70 & 20.01 & 6.74 & 13.87 & 1.73 & 4.35 & 1.18 & 3.06 & 2.01 & 0.70 & 0.20 & 0.08 \\
\hline
\end{tabular}

Espinhaço, Chapada Diamantina (McReath, et al. 1981), que também ocorrem intercaladas a metaconglomerados e foram datadas em $1752 \pm 4 \mathrm{Ma}$ (Schobbenhaus et al. 1994). Uma amostra de meta-traquiandesito basáltico com elevados teores possivelmente primários de $\mathrm{K}_{2} \mathrm{O}$ e outros elementos litófilos mostra teores relativamente altos de $\mathrm{Zr}, \mathrm{Y}$ e Th, também típicos de magmatismo intraplaca, e sugere caráter bimodal para a seqüência.

O corpo anfibolítico do Jaraguá, com mineralogia à base de hornblenda, plagioclásio, epidoto e titanita, apresenta características geoquímicas mais pró- ximas de magmatismo de fundo oceânico, com baixas concentrações de elementos incompatíveis como $\mathrm{Rb}$, $\mathrm{Nb}$ e Th. Nesse sentido, embora de idade ainda desconhecida, mostra semelhanças com as rochas metabásicas da região de Pirapora do Bom Jesus (Lazzari 1987; Tassinari et al. 2001).

Agradecimentos Os autores agradecem ao Conselho Nacional de Pesquisa (CNPq), pelo apoio fornecido a esta pesquisa.

\section{Referências}

Almeida F.F.M. de, Hasui Y., Brito Neves B.B., Fuck R.A. 1981. Brazilian Structural Provinces: An Introduction. Earth-Science Reviews, 17(1/2):1-29.

Basei M.A.S., Siga Jr. O., Kaulfuss G.A., Cordeiro H., Nutman A., Sato K., Cury L.F., Prazeres Filho H. J., Passarelli C.R., Harara O.M., Reis Neto J.M., Weber W. 2003. Geochronology and isotope geochemistry of Votuverava and Perau Mesoproterozoic basins, southern Ribeira Belt, Brazil, South American Symposium on Isotope Geology, 4, Salvador, Brazil, Short Papers, p.501-504.
Bergmann M. 1988. Caracterização Estratigráfica e Estrutural da Seqüencia Vulcano-Sedimentar do Grupo São Roque na Região de Pirapora do Bom Jesus - Estado de São Paulo. Dissertação de Mestrado, Instituto de Geociências USP, $167 \mathrm{p}$.

Brito Neves B.B. de, Kawashita K., Cordani U.G., Delhal J. 1979. A Evolução Geocronológica da Cordilheira do Espinhaço; Dados Novos e Integração. Revista Brasileira de Geociências, 9: 71-85.

Brito Neves B.B. de, Sá de J.M., Nilson F.B. 1995. A Ta- 
frogênese Estateriana nos Blocos Paleoproterozóicos da América do Sul e Processos Subseqüentes. Geonomos, 3(2):1-21.

Campanha G.A. da C. \& Sadowski G.R. 1999. Tectonics of the southern portion of the Ribeira Bellt (Apiaí Domain). Precambrian Research, 98:31-51.

Campos Neto M. da C., Basei M.A.S., Artur A.C., Silva M.E. da, Machado R., Dias Neto C. de M., Fragoso Cesar A.R., Souza A.P. 1983. Geologia das Folhas Piracaia e Igaratá. In: IPT - Pró-Minério, Jornada Sobre a Carta Geológica do Estado de São Paulo em 1: 50.000, 1, São Paulo, Atas, p. 55-76.

Campos Neto M. da C. \& Figueiredo M.C.H. 1995. The Rio Doce Orogeny, Southeastern Brazil. Journal of South American Earth Sciences, 8(2):143-162.

Campos Neto M. da C. 2000. Orogenic Systems From Southwestern Gondwana: an Approach to Brasiliano-Pan African Cycle and Orogênic Collage in Southeastern Brazil. In: Cordani U.G., Milani E.J., Thomaz Filho A., Campos D.A. (eds.) Tectonic Evolution of South American. In: International Geological Congress, 31, Rio de Janeiro, Brazil, p. 335-365.

Carneiro C.D.R. 1983. Análise Estrutural do Grupo São Roque na Faixa entre o Pico do Jaraguá e a Serra dos Cristais, SP. Tese de Doutoramento, Instituto de Geociências, USP, $155 \mathrm{p}$.

Carneiro C.D.R., Hasui Y., Dantas A.S.L. 1984. Contribuição ao Estudo da Litoestratigrafia do Grupo São Roque na Faixa Jaraguá-Cristais-SP. In: Congresso Brasileiro de Geologia, 33, Rio de Janeiro (RJ), Anais, p.3212-3226.

Condie C.K. 2002. Breakup of a Paleoproterozoic Supercontinent. Gondwana Research, 5(1):41-43.

Cordani U.G., Campos A.C.R., Davino A., Björnber A.J.S. 1961. Geologia da Região do Jaraguá. Boletim da Sociedade Brasileira de Geologia, 10(20):73-91.

Cordani U.G., Gomes C. de B., Girardi V.A.V. 1963. Rochas Cálcio-Silicatadas da Região de Perus, SP. Anais da Academia Brasileira de Ciências, 35(3):361-372.

Coutinho J.M.V. 1955. Metaconglomerado e rochas associadas no Município de São Paulo. Boletim da Faculdade de Filosofia, Ciências e Letras - Universidade de São Paulo, São Paulo, 186(13):5-56.

Coutinho J.M.V. 1968. Petrologia do Pré-Cambriano em São Paulo e Arredores. Tese de Professor Catedrático, Faculdade de Filosofia Ciências e Letras, USP, 174 p.

Coutinho J.M.V., Rodrigues E de P., Suemitsu A., Juliani C., Beljavskis P., Paulo de T.Y.P. 1982. Geologia e Petrologia da Seqüência Vulcano-Sedimentar do Grupo São Roque na Serra de Itaberaba - SP. In: Congresso Brasileiro de Geologia, 32, Salvador, Bahia, Anais, 2:624-640.

Dantas A.S.L. 1990. Geologia da Faixa São Roque e Intrusivas Associadas na Região entre São Paulo e Mairiporã, Norte de São Paulo. Dissertação de Mestrado, Instituto de Geociências, USP, 199 p.

Derby O.A. 1895. A denominação "Serra da Mantiqueira". Revista do Instituto Historico e Geografico de São Paulo, 1:5-15.

Eschwege W.L. Von. 1824. Brasil, novo mundo. Tradução Domício de Figueiredo Murta. Centro de Estudos Históricos e Culturais. Belo Horizonte, Fundação João Pi- nheiro, 1996, $197 \mathrm{p}$.

Fernandes da Silva P.C. 2004. Litofácies e Prováveis Ambientes de Sedimentação do Grupo São Roque na Região de Votorantim e Salto de Pirapora, SP. Revista do Instituto Geológico, São Paulo, 25 (1/2):29-48.

Gomes C de Barros. 1962. Contribuição ao Conhecimento dos Anfibolitos da Região do Jaraguá, SP. Boletim Sociedade Brasileira de Geologia, 11(1):57-73.

Gonzaga de Campos L.F. 1888. Secção Geológica. Relatório apresentado ao Dr. Orville A. Derby. Relatório da Commisão Geographica e Geológica da Província de São Paulo. São Paulo, Typographia a Vapor de Jorge Seckler \& Comp., 15 de Dezembro, p.21-34.

Hackspacher P.C., Dantas E.L., Spoladore A., Fetter A.H., Oliveira M.A.F. 2000. Evidence for Neoproterozoic back-arc basin development in the Central Ribeira Belt, southeastern Brazil: new geochronological and geochemical constraints from the São Roque-Açungui Groups. Revista Brasileira de Geociencias, 30:110-114.

Hasui Y., Penalva F., Hennies W.T. 1969. Geologia do Grupo São Roque. In: Congresso Brasileiro de Geologia, 23, Salvador (BA), Anais, 101-134.

Hasui Y. 1973. Tectônica da área das folhas de São Roque e Pilar do Sul. São Paulo. Tese Livre-Docência, Instituto de Geociências, USP, 134 p.

Hasui Y. 1975b. Geologia da Folha de São Roque. Boletim do Instituto de Geociências USP, 6:157-183.

Hasui Y., Carneiro C.D.R., Coimbra A.M. 1975a. The Ribeira Folded Belt. Revista Brasileira de Geociências, 5:257-266.

Hasui Y. \& Sadowski G. R. 1976. Evolução geológica do Pré-cambriano na região sudeste do Estado de São Paulo. Revista Brasileira de Geociências, 6(3):182-200.

Hasui Y., Tognon A.A., Soares L., Csordas S.M. 1978. Geologia e Tectônica da Serra do Japí. Boletim Instituto de Geociências USP, 9:17-24.

Henrique-Pinto R. \& Janasi V.A. 2007. Proveniência dos Metaconglomerados do Grupo São Roque (SP): contribuições a partir da geoquímica dos seixos graníticos. In: Congresso Brasileiro de Geoquímica, 11, Atibaia (SP), Resumos Expandidos, p. 1-4.

Henrique-Pinto R. 2008. Metaconglomerados e Rochas Associadas do Grupo São Roque a Noroeste da Cidade de São Paulo: Proveniência e Implicações para a Idade da Sedimentação. Dissertação de Mestrado, Programa de Pós-Graduação em Mineralogia e Petrologia, Universidade de São Paulo, 82 p.

INSTITUTO DE PESQUISAS TECNOLÓGICAS (IPT). 1983. Carta Geológica do Estado de São Paulo em Escala 1:50.000. Secretaria da Industria, Comércio, Ciência e Tecnologia - Pró-Minério.

Irvine T.N. \& Baragar W.R.A. 1971. A Guide to the Chemical Classification of the Common Volcanic Rocks. Canadian Journal of Earth Sciences, 8:523-548.

Janasi V.A. \& Ulbrich H.H.G.J. 1991. Late Proterozoic granitoid magmatism in the state of São Paulo, southeastern Brazil. Precambrian Research, 51:351-374.

Juliani C. 1993. Geologia, Petrogênese e Aspectos Metalogenéticos dos Grupos Serra do Itaberaba e São Roque na Região das Serras do Itaberaba e Pedra Branca, NE 
da Cidade de São Paulo, SP. São Paulo, Tese de Doutorado, Instituto de Geociências, USP, 803 p.

Juliani C., Beljavskis P., Schorscher H.D. 1986. Petrogênese do Vulcanismo e Aspectos Metalogenéticos Associados: Grupo Serra do Itaberaba na Região do São Roque SP. In: Congresso Brasileiro de Geologia, 34, Goiânia, Anais, 2:730-745.

Juliani C., Martin M.A.B., Clarimundo S. de J. 1997. Os metarcoseos do Morro do Polvilho: implicações para geocronologia e para evolução crustal dos grupos Serra do Itaberaba e São Roque (SP). Anais da Academia Brasileira de Ciencias, 69:441.

Juliani C., Martin M.A.B., Clarimundo S. de J., McReath I., Pertersen Jr. K.J. 1999. Geologia dos Grupos Serra do Itaberaba e São Roque entre o Pico do Jaraguá e Araçarigüama, São Paulo. In: SBG/NSP-NRJ/ES, Simpósio de Geologia do Sudeste, Águas de São Pedro, Boletim de Resumos, 6:26.

Juliani C., Hackspaker P., Dantas E.L., Fetter A.H. 2000. The Mesoproterozoic volcano-sedimentary Serra do Itaberaba Group of the central Ribeira Belt, São Paulo, Brazil: implications for the age of the overlying São Roque Group. Revista Brasileira de Geociências, 30:82-86.

Lazzari M.L. 1987. O Metabasito de Pirapora do Bom Jesus. Dissertação de Mestrado, Instituto de Geociências, Universidade de São Paulo, 84 p.

Le Bas M.J., Le Maitre R.W., Streckeisen A., Zanettin. 1986. A Chemical Classification of Volcanic Rocks Based on Total Alkali-Silica Diagram. Journal of Petrology, 27(3):745-750.

Martin M.A.B. 2000. Geologia e Petrografia e Metamorfismo dos Grupos Serra do Itaberaba e São Roque a Noroeste da Cidade de São Paulo (SP). Dissertação de Mestrado, Instituto de Geociências, USP, 256 p.

McReath I., Jardim de Sá E.F., Fryer B.J. 1981. As Vulcânicas Ácidas Proterozóicas da Região da Bacia do Rio Paramirim - Bahia. Geologia e Recursos Minerais do Estado da Bahia. Secr. de Minas e Energia, 4:121-134.

Moraes L.J. de. 1944. A Serra do Japí, Estado de São Paulo. Boletim da Faculdade de Filosofia, Ciências e Letras Universidade de São Paulo, 45(1):34-40.

Moraes Rego L.F. de. 1931. As estructuras antigas do Brasil. Annaes da Escola de Minas, 27-85.

Moraes Rego L.F. de. 1933. Contribuição ao estudo das formações pré-devonianas de São Paulo. Boletim do Instituto Astronômico e Geographico. São Paulo - SP, 55p.

Oliveira E.P. de. 1925. Analyses de Calcareos. Serviço Geológico e Mineralógico do Brasil. Ministério da Agricultura Indústria e Commercio. Boletim 10:1-45.

Oliveira F de P. 1887. Esboço Geológico da Região Comprehendida entre os Rios Sorocaba e Tieté. Relatório da Província de São Paulo, Commissão Geographica e Geológica. São Paulo, Typographia a Vapor de Jorge Seckler \& Comp., 19 de novembro, p. 26-28.

Oliveira M.A.F de, Melo R.P., Nardy A.J.R., Arab P.B., Trindade I. 2008. New U/Pb Palaeoproterozoic Zircon Age For The Cajamar Metabasite, São Roque Group, Central Ribeira Belt, Southeastern Brazil. In: South Americam Symposium on Isotope Geology, 6, San Carlos de
Bariloche, Argentina, Actas, p.1-4.

Paoliello P.C. 1964. Geologia do Estado de São Paulo - Explanação do Mapa Geológico. Boletim do Instituto Geográfico e Geológico de São Paulo, 41:37-44.

Pearce J.A \& Cann J.R. 1973. Tectonic Setting of Basic Volcanic Rocks Determined Using Trace Element Analyses. Earth and Planetary Science Letters, 19(2):290-300.

Pearce J.A \& Norry M.J. 1979. Petrogenetic Implications of $\mathrm{Ti}, \mathrm{Zr}, \mathrm{Y}$, and $\mathrm{Nb}$ Variations in Volcanic Rocks. Contributions to Mineralogy and Petrology, 69:33-47.

Pearce J.A., Harris N.B.W., Tindle A.G. 1984. Trace Element Discrimination for the Tectonic Interpretation of Granitic Rocks. Journal of Petrology, 25(4):956-983.

Rogers J.W. \& Santosh M. 2002. Configuration of Columbia, a Mesoproterozoic Supercontinent. Gondwana Research, 5(1):5-22.

Schobbenhaus C., Hoppe A., Baumann A., Lork A. 1994. Idade U/Pb do Vulcanismo Rio dos Remédios, Chapada Diamantina, Bahia. In: Congresso Brasileiro de Geologia, 38, Balneário Camboriú (SC), Anais, p. 397-398.

Tassinari C.C.G., Kawashita K., Kikuchi R.K.P. 1985. Estudo Geocronológico nos Metaconglomerados do Grupo São Roque, Estado de São Paulo. In: SBG, Simpósio Regional de Geologia, 10, São Paulo, Boletim de Resumos, 1:201-208.

Tassinari C.C.G., Munhá J.M.U., Correia C.T. 2001. Neoproterozoic Oceans in the Ribeira Belt (southeastern Brazil): The Pirapora do Bom Jesus Ophiolitic Complex. Episodes, 24(4):245-251.

Taylor S. R. \& Mclennan S. M. 1985. The Continental Crust: Its Composition and Evolution. Oxford, Blackwell,234p.

Turra B.B., Campanha G.A.C., Henrique-Pinto R. 2007. Análise de Deformação nos Metaconglomerados do Morro Doce, Grupo São Roque, Faixa Ribeira ao Norte da Cidade de São Paulo. In: Simpósio de Geologia de Minas Gerais, 14, e Simpósio de Geologia do Sudeste, 10, Diamantina (MG), Livro de Resumos, p. 19.

Van Schmus W.R., Tassinari C.C.G., Cordani U.G. 1986. Estudo Geocronológico da Parte Inferior do Grupo São Roque. In: Congresso Brasileiro de Geologia, 34, Goiânia (GO), Anais, 3:1399 - 1406.

Weber W., Siga Jr. O., Sato K., Reis Neto J.M dos, Basei M.A.S., Nutman A.P. 2004. A Formação Água Clara na Região de Araçaíba - SP: Registro U-Pb de Uma Bacia Mesoproterozóica. Geologia USP - Série Científica, 4(1):101-110.

Wedepohl K.H. 1995. The composition of the continental crust. Geochimica et Cosmochimica Acta, 59(7): 12171232.

Vermeesh P. 2006. Tectonic Discrimination Diagrams Revisited. Geochemistry Geophysics Geosystems, 7(6):1-55.

Wernick E., Oliveira M.A.F. de, Kawashita K., Cordani U.G., Delhal J. 1976. Estudo Geocronológico pelo Método Rb/ Sr em Rochas do Bloco Jundiaí e Regiões Adjacentes. Revista Brasileira de Geociências, 6(2):125-135.

Manuscrito ID 16307

Submissão em 09 de dezembro de 2009 Aceite em 15 de setembro de 2010 